\title{
Release and intestinal translocation of chemicals associated with microplastics in an in vitro human gastrointestinal digestion model
}

Ruud Peters ${ }^{1 *}$, Nadine de Jong ${ }^{2}$, Laura de Haan², Stephanie Wright ${ }^{3}$ and Hans Bouwmeester ${ }^{2^{*}}$ (D)

\begin{abstract}
The global production of plastic currently exceeds 300 million tonnes per year. The extensive use of plastics and bad waste management has resulted in the presence of microplastics at different levels in the food production chain. From a chemical perspective, these microplastics are complex mixtures that contain multiple additives, such as plasticizers, flame retardants, stabilizers and pigments. Also other chemicals can be present in microplastics, including unreacted monomers, starting substances, and non-intentionally added substances. Finally, the microplastics may have adsorbed environmental contaminants. In this study we have used several types of microplastics, either from grinded beach litter or from frequently used food packing materials and pre-production samples. We quantified the chemical and metal release from these microplastics in worst case and physiological scenarios. We use a chemical extraction as worst case, and for the physiological scenarios we used an in vitro model of the human digestion and an in vitro model of the human intestinal epithelium. Subsequently all samples were analysed with sensitive ICP-MS, GCMS methods. We quantified 68 chemicals and 29 metals associated with a diversity of microplastics, some of these chemicals were also released in the luminal content of the human digestive tract under physiological conditions simulated in vitro. Only 22 chemicals reached the basolateral compartment of an in vitro intestinal epithelial model. From the ToxCast dataset we extracted 18 AOPs that were associated with the chemicals, that included AOPs associated with endocrine disruption. For a risk assessment of chemicals associated with microplastics more detailed data on oral microplastics exposure is needed, as well as more detailed toxicological studies on the hazards of both the individual and complex mixtures of the quantified chemicals. Keywords: Microplastics, Gut barrier, Organic chemicals, Endocrine disruption, In vitro digestion
\end{abstract}

\footnotetext{
*Correspondence: ruudj.peters@wur.nl; hans.bouwmeester@wur.nl

${ }^{1}$ Wageningen Food Safety Research, Wageningen University \& Research,

Wageningen, The Netherlands

${ }^{2}$ Division of Toxicology, Wageningen University \& Research, Wageningen, the Netherlands

Full list of author information is available at the end of the article
}

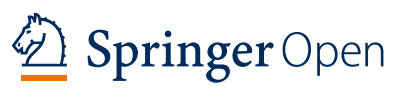

(c) The Author(s). 2022 Open Access This article is licensed under a Creative Commons Attribution 4.0 International License, which permits use, sharing, adaptation, distribution and reproduction in any medium or format, as long as you give appropriate credit to the original author(s) and the source, provide a link to the Creative Commons licence, and indicate if changes were made. The images or other third party material in this article are included in the article's Creative Commons licence, unless indicated otherwise in a credit line to the material. If material is not included in the article's Creative Commons licence and your intended use is not permitted by statutory regulation or exceeds the permitted use, you will need to obtain permission directly from the copyright holder. To view a copy of this licence, visit http://creativecommons.org/licenses/by/4.0/. 


\section{Introduction}

Worldwide more than 320 million tonnes of plastic are produced annually, and production is growing exponentially $[1,2]$. From a materials perspective, plastics are cheap and versatile and thus are an integral part of our everyday lives. However, microscopic particles are released from plastic throughout it's lifecycle, via abrasion and/or photochemical degradation and subsequent fragmentation during use, disposal or systems leakage [3, 4]. The particles are known as microplastic and measure less than $5 \mathrm{~mm}$ in their maximum dimension, whilst those particles measuring between $1 \mu \mathrm{m}$ and $100 \mathrm{~nm}$ are defined as submicron plastics [5] or those smaller than $100 \mathrm{~nm}$ according to the European Food Safety Authority (EFSA) [5-8]. The broad range of applications for plastic material means there is a wide variety of sources of microplastic, such as plastic debris, synthetic clothing, personal care products containing plastic microbeads, industrial scrubbing agents and the leakage of virgin pellets, each which are diverse in their polymer composition. The most commonly produced types of polymers are polyethylene (PE), polypropylene (PP) and polystyrene (PS) however the polymer composition of microplastics in realistic (environmental) samples is very heterogeneous $[9,10]$.

For humans, the oral route represents an important exposure pathway for microplastics [11, 12], evidenced by the presence of microplastics in human stool [13]. Microplastic contaminates seafood [14], and other food commodities [15, 16]. In the European Commission's Rapid Alert System for Food and Feed (RASFF), microplastics (classified as foreign bodies) are reported to not only be present in seafood, but for instance also in oligo fructose powder, pickled products and frozen vegetable spring rolls [17]. Microplastics are also found in drinking water from plastic bottles, glass bottles, beverage cartons and in tap water from different countries [18, 19]. Several analytical approaches have been developed to study the presence of microplastics in different matrices, yet given the complexity of the polymer composition and size ranges of microplastics accurately characterising the occurrence and thus predicting human exposure remains challenging [20]. Recently the human intake of microplastics from food was estimated to be 39,000 to 52,000 particles per year depending on age and gender, from different food groups, which together accounted for $15 \%$ of the daily average caloric intake consumed by adults in the US, including seafood, water, sugar, salt and honey [21, 22]. Airborne microplastics also provide an important source of microplastics to which humans eventually can be orally exposed. Inhaled microplastics can be swallowed after lung clearance via the mucociliary escalator and end up in the gut [11]. Alternatively airborne microplastics may settle on food and beverages during consumption [23]. Together this might increase the human body burden of microplastics.

Plastic products and thus the microplastics degraded from these products are complex chemical mixtures containing multiple additives, such as plasticizers, flame retardants, stabilizers, antioxidants, fillers and pigments to improve the polymers functionality and characteristics $[24,25]$. Chemicals in plastics include phthalates, bisphenol A (BPA), polybrominated diphenyl ethers (PBDE), tetrabromobisphenol A (TBBPA), alkylphenols and organotin compounds [26, 27]. In addition to these additives, other chemicals are present in plastics, including unreacted monomers and non-intentionally added substances (NIAS) [28]. Moreover, and due to their relatively large specific surface area and inherent hydrophobicity, microplastics can adsorb and concentrate pollutant chemicals from the ambient environment $[29,30]$. Well-known examples of these are persistent organic pollutants (POP) such as polychlorinated biphenyls (PCB), polycyclic aromatic hydrocarbons (PAH), dioxin-like chemicals, polybrominated diphenyl ethers (PBDE), pharmaceuticals. In addition metals can be present in microplastics as some of them are used as additive, or adsorb to microplastics from the environment [31-38].

As most of these chemicals are not covalently bound to the polymer, they are susceptible to leaching to the surrounding medium at all stages of the plastics' lifecycle. Such leaching is enhanced at physiological temperature, low $\mathrm{pH}$ [39] and in lipid-rich environments [40]. Hence, there is potential for the environmental conditions of the human digestive tract to facilitate chemical leaching from microplastic, contributing to daily intakes and body burdens. The relative importance of such physiological digestion is yet to be determined. The aim of this study is to identify whether chemicals leach out of different types of microplastics. We have selected a range of different microplastics, ranging from microplastics derived from plastic beach litter [9], different pre-production microplastics to which humans might be exposed and that are frequently used in toxicological studies (i.e. polyvinylchloride (PVC), PE, PS, PP and polyamide (PA)) [41]. Lastly we used post production microplastics derived from a PP food container [42] and polyethylene terephthalate (PET) from a single use plastic water bottle [43]. We have used two different approaches in our studies. First, an in vitro model of the human digestive system and sensitive ICP-MS and GCMS methods are used to identify which chemicals can leach out of different types of plastics before and after in vitro digestion. Secondly, an in vitro transport study using a well-established intestinal Caco-2 Transwell model is used to evaluate the in vitro translocation of the microplastic associated chemicals (see Fig. 1). In 


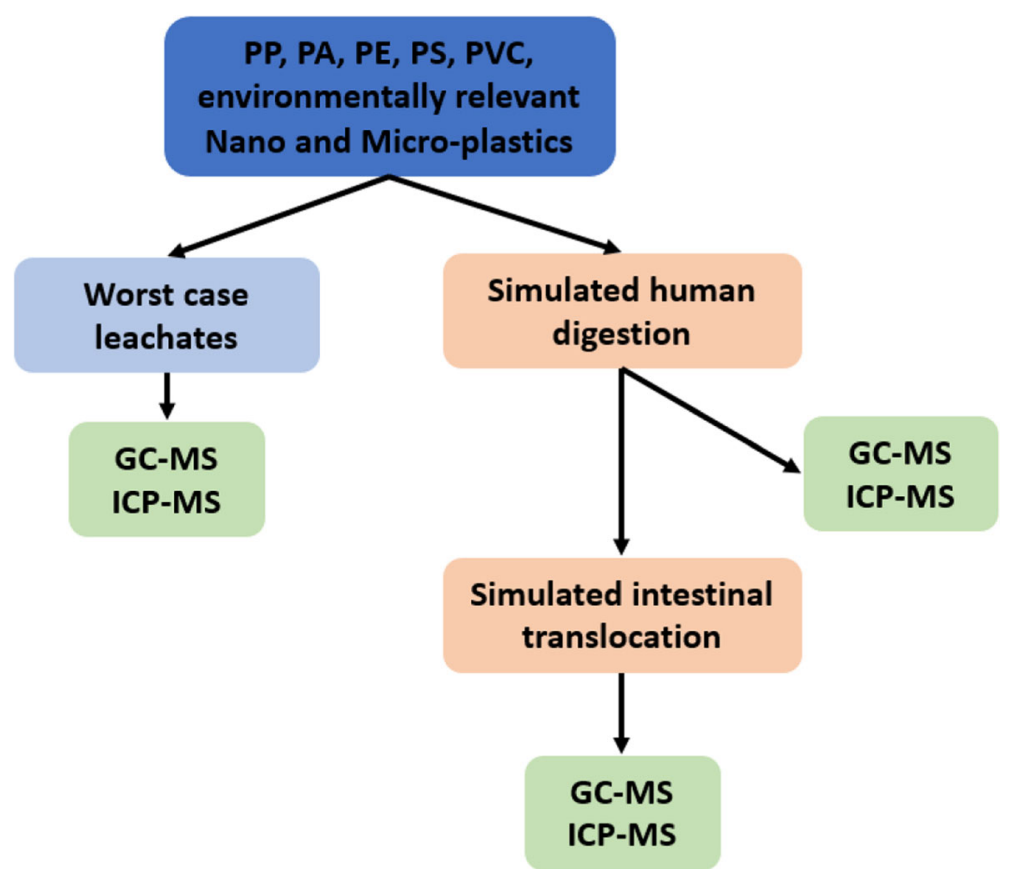

Fig. 1 Experimental design. Environmental microplastic $<1 \mathrm{~mm}$ and $<3 \mathrm{~mm}$; PA: polyamide; PE: Polyethylene; PET: Polyethylene terephthalate; PP: Polypropylene; PS: Polystyrene; PVC: Polyvinylchloride. For details see materials and methods

addition, the potential toxicity of the translocated chemicals was investigated using effect studies from the TOXcast programme resulting in an initial risk assessment of the human oral exposure to these microplastics.

\section{Material and methods \\ Samples}

Nine types of microplastics were used in this study. Two types of environmentally relevant microplastics were prepared by Kühn et al. (2018) from plastic litter collected on Dutch beaches, which were cryomilled to particle sizes of 1 and $3 \mathrm{~mm}$ (ENV1 and ENV2) [9].

The following pre-production plastic powders were used: polyvinylchloride, unplasticized (PVC); polyethylene (PE); polystyrene (PS); and polyamide (PA), all purchased from Goodfellow Cambridge Ltd. (UK). All but PVC had been cryo-milled before use in clean zirconium oxide grinding jars $(25 \mathrm{~mL})$ with approximately 200 zirconium oxide grinding balls $(5 \mathrm{~mm})$ at $30 \mathrm{~Hz}$ for $20-60$ $\mathrm{min}$, depending on the polymer, with automatic precooling. Pre-production polypropylene (PP1) powder was kindly provided as a sample from Diamond Plastics GMBH (Germany). Post-production plastic powders were fabricated from a brand-new polypropylene (PP2) takeaway food container and brand-new polyethylene terephthalate (PET) single-use plastic water bottle, the contents of which were first discarded. Pieces had similarly been cryo-milled before use in a $50 \mathrm{~mL}$ jar with a steel ball $(25 \mathrm{~mm})$ using the following programme: $6 \mathrm{~min}$ precool, $4 \times 2$ min milling cycles, $45 \mathrm{~s}$ intermediate cooling between cycles. Collectively, these powders represent a) polymers commonly used and encountered as microplastic in daily life and b) use cases of polymers which may contribute to oral microplastic exposure and contain a representative additive profile. All powders were stored and provided dry in glass vials with white plastic (PP) caps. The vials were rinsed with $\mathrm{MeOH}$, rinsed three times with ultrapure water, then oven dried. The caps were rinsed in $\mathrm{MeOH}$ and left to air dry (face down). The vials were further individually wrapped in aluminium foil to keep the contents in the dark. The powders were also sized. Briefly, an ad hoc mass was combined with $1 \mathrm{~mL}$ of $\mathrm{EtOH}$ in an Eppendorf tube to create a suspension. Five-microlitre drop casts were then prepared on clean, plain microscope slides. The drop cast was viewed under a microscope (OLYMPUS BX53). Following a north-south transect through the middle of the drop cast, intercepted particles were viewed at 100500x magnification and sized in OLYMPUS Stream Start software (Table 1).

\section{Assessment of worst case chemical leachates from microplastics}

For the determination of organic compounds $50 \mathrm{mg}$ of microplastic material was ultrasonically extracted for 10 min with $2 \mathrm{~mL}$ of ethyl acetate (ENV1, ENV2, PE, PP1, PP2, PET, PA) or acetonitrile (PS and PVC). Acetonitrile was used for the extraction of PS and PVC since these 
Table 1 The particle size ( $\mu \mathrm{m})$ of test polymers

\begin{tabular}{llllllll}
\hline & PA & PE & PET bottle & PP 1 & PP 2 (food container) & PS & PVC \\
\hline Mean & 9.13 & 18.79 & 6.43 & 11.11 & 4.36 & 3.55 & 33.80 \\
St. Dev. & 8.17 & 30.29 & 27.00 & 13.74 & 3.05 & 25.92 & 53.78 \\
Min. & 0.35 & 0.80 & 0.93 & 0.60 & 0.93 & 3.40 & 2.76 \\
D 10 & 0.86 & 1.39 & 1.48 & 2.09 & 1.56 & 8.79 & 3.06 \\
Median & 8.41 & 5.00 & 2.76 & 6.37 & 3.67 & 20.01 \\
D90 & 19.80 & 42.61 & 6.54 & 26.87 & 9.07 & 53.08 \\
Max. & 42.03 & 224.55 & 283.16 & 121.31 & 14.50 & 128.87 \\
\hline
\end{tabular}

Min. minimum size, Max. maximum size, D10 the particle size which $10 \%$ of the particle population were less than, by count, D90 the particle size which $90 \%$ of the particle population were less than, by count, St. Dev. standard deviation, PA polyamide, $P E$ ultra-high molecular weight polyethylene, $P E T$ polyethylene terephthalate, $P P$ polypropylene, $P S$ polystyrene, $P V C$ polyvinylchloride

tend to dissolve in ethyl acetate. ${ }^{13} \mathrm{C}-\mathrm{PCB}-209$ was added as an internal standard. The extracts were filtered through a small column of glass wool and sodium sulphate to remove the plastic particles. $100 \mu \mathrm{L}$ of the extracts were analysed with GCxGC-TOFMS as described above. A sequential extraction was carried out on the extracted microplastic residue of the environmental microplastics which are believed to contain absorbed additives as well as adsorbed contaminants. The results showed that $>90 \%$ of the organic compounds were recovered in the first extraction. The filtration step was tested with a suite of representative organic compounds and showed that no absorption occurred during filtration of the extract. Procedural blanks were included and showed low levels of interfering phthalates. Results were corrected for these blank findings.

For the determination of elements $50 \mathrm{mg}$ of plastic was combined with $3 \mathrm{~mL}$ of nitric acid (HNO3, 70\%) in a glass microwave digestion tube. The samples were digested in a Discover microwave system and the temperature program was as follows: $1600 \mathrm{~W}$ power from 20 to $120^{\circ} \mathrm{C}$ in $15 \mathrm{~min}$, then to $160^{\circ} \mathrm{C}$ in $10 \mathrm{~min}$, and then to $210^{\circ} \mathrm{C}$ in $30 \mathrm{~min}$ and hold for $1 \mathrm{~min}$. Following digestion and cooling to room temperature, rhodium was added as an internal standard and the extract was diluted with ultrapure water to a concentration of $3 \%$
$\mathrm{HNO}_{3}$ (and further with $3 \% \mathrm{HNO}_{3}$ to fit the calibration line) and the extract was analysed with ICP-MS. Reference materials BCR-680 and -681 [44] were analysed using the same method and showed good recoveries of the target elements in the range of $89-107 \%$. Procedural blanks were included and showed no interfering elements.

\section{Assessment of chemical leachates from microplastics during in vitro human intestinal digestion}

An in vitro human digestion model was used to determine the potential release of chemicals from microplastics during human digestion. The in vitro digestion model consists of three steps: saliva, gastric and intestine digestion. Artificial digestive juices for the digestion experiments were prepared on the day before the actual digestions. The constituents and concentrations of these juices are listed in Table 2 (from [45, 46]. The in vitro digestion starts by introducing $2 \mathrm{~mL}$ of artificial saliva to $100 \mathrm{mg}$ of microplastic in amber $15 \mathrm{~mL}$ glass tubes closed with a screw cap with a Teflon insert. This mixture is rotated (head-over-heals) for $5 \mathrm{~min}$ at $55 \mathrm{rpm}$ at $37^{\circ} \mathrm{C}$. For the next step, $4 \mathrm{~mL}$ of gastric juice is added to the mixture and the $\mathrm{pH}$ is adjusted to $\mathrm{pH} 2.0 \pm 0.5$ with hydrochloric acid $(\mathrm{HCl}, 37 \% \mathrm{w} / \mathrm{w})$. The mixture is rotated for $2 \mathrm{~h}$. Finally, $4 \mathrm{~mL}$ of duodenal juice, $2 \mathrm{~mL}$ of bile juice, and $0.5 \mathrm{~mL}$ of $\mathrm{NaHCO}_{3}$ solution are added to

Table 2 Composition of juices of the in vitro digestion model (amounts based on $1000 \mathrm{ml}$ juice) [45]

\begin{tabular}{|c|c|c|c|}
\hline Saliva (pH $6.8 \pm 0.1)$ & Gastric juice $(\mathrm{pH} 1.3 \pm 0.1)$ & Duodenal juice $(\mathrm{pH} 8.1 \pm 0.1)$ & Bile juice (pH $8.2 \pm 0.1)$ \\
\hline $\begin{array}{l}896 \mathrm{mg} \mathrm{KCl} \\
200 \mathrm{mg} \mathrm{KSCN} \\
1021 \mathrm{mg} \mathrm{NaH} 2 \mathrm{PO} 4 \_H 2 O \\
570 \mathrm{mg} \mathrm{Na} 2 \mathrm{SO} 4 \\
298 \mathrm{mg} \mathrm{NaCl} \\
1694 \mathrm{mg} \mathrm{NaHCO} 3 \\
200 \mathrm{mg} \text { urea } \\
290 \mathrm{mg} \text { amylase } \\
15 \mathrm{mg} \text { uric acid } \\
25 \mathrm{mg} \text { mucin } \\
\text { Milli-Q water }\end{array}$ & $\begin{array}{l}2752 \mathrm{mg} \mathrm{NaCl} \\
306 \mathrm{mg} \mathrm{NaH} 2 \mathrm{PO} 4 \mathrm{H} 2 \mathrm{O} \\
824 \mathrm{mg} \mathrm{KCl} \\
302 \mathrm{mg} \mathrm{CaCl} 2 \\
306 \mathrm{mg} \mathrm{NH} 4 \mathrm{Cl} \\
6.5 \mathrm{ml} \mathrm{37 \%} \mathrm{HCl} \\
650 \mathrm{mg} \text { glucose } \\
20 \mathrm{mg} \text { glucuronic acid } \\
85 \mathrm{mg} \text { urea } \\
330 \mathrm{mg} \text { glucosaminehydrochloride } \\
1 \mathrm{~g} \mathrm{BSA} \\
2.5 \mathrm{~g} \text { pepsin } \\
3 \mathrm{~g} \text { mucin } \\
\text { Milli-Q water }\end{array}$ & $\begin{array}{l}7012 \mathrm{mg} \mathrm{NaCl} \\
3388 \mathrm{mg} \mathrm{NaHCO} 3 \\
80 \mathrm{mg} \mathrm{KH} 2 \mathrm{PO} 4 \\
564 \mathrm{mg} \mathrm{KCl} \\
50 \mathrm{mg} \mathrm{MgCl} 2 \_6 \mathrm{H} 2 \mathrm{O} \\
180 \mathrm{ml} \mathrm{HCl}(37 \%) \\
100 \mathrm{mg} \mathrm{urea} \\
151 \mathrm{mg} \mathrm{CaCl} 2 \\
1 \mathrm{~g} \mathrm{BSA} \\
9 \mathrm{~g} \text { pancreatin } \\
1.5 \mathrm{~g} \text { lipase } \\
\text { Milli-Q water }\end{array}$ & $\begin{array}{l}5259 \mathrm{mg} \mathrm{NaCl} \\
5785 \mathrm{mg} \mathrm{NaHCO} 3 \\
376 \mathrm{mg} \mathrm{KCl} \\
150 \mathrm{ml} \mathrm{HCl} \mathrm{(37 \% )} \\
250 \mathrm{mg} \text { urea } \\
167.5 \mathrm{mg} \mathrm{CaCl} 2 \\
1.8 \mathrm{~g} \mathrm{BSA} \\
30 \mathrm{~g} \text { bile } \\
\text { Milli-Q water } \\
\text { Sodium carbonate solution } \\
84.7 \mathrm{~g} \mathrm{NaHCO} 3 \\
\text { Milli-Q water }\end{array}$ \\
\hline
\end{tabular}


the mixture and the mixture $\mathrm{pH}$ is adjusted to $\mathrm{pH} 6.5 \pm$ 0.5 with $\mathrm{NaOH}(1 \mathrm{M})$. The mixture is rotated for another $2 \mathrm{~h}$. After this period a subsample of $4 \mathrm{ml}$ is collected for the in vitro translocation experiment while the remainder of the mixture is filtered over a $0.45 \mu \mathrm{m}$ filter to remove the microplastics.

A subsample of $8 \mathrm{ml}$ of the filtrate is extracted with 4 $\mathrm{ml}$ of ethyl acetate after addition of the ${ }^{13} \mathrm{C}$-PCB-209 internal standard, the extract is dried with sodium sulphate and $100 \mu \mathrm{l}$ of the extract is analysed with GCxGC-TOFMS as described above to determine the organic chemicals released by the microplastics during digestion. For identification a dedicated library was used that was compiled from the compounds that were identified in the initial chemical analysis of the microplastics. The aqueous phase is left over night for the residue ethyl acetate to evaporate. Next, a subsample of $4 \mathrm{ml}$ of the aqueous phase is collected, acidified with nitric acid to $3 \% \mathrm{HNO}_{3}$, and after addition of rhodium as the internal standard analysed with ICP-MS as described above to determine the elements released by the microplastics during digestion.

\section{Determination of translocation of chemical leachates from microplastics using intestinal Caco-2/HT29-MTX cell layers}

Caco2/HT29-MTX cells were used to prepare an in vitro monolayer of intestinal cells in a 12 -well plate with Transwell inserts. The human colonic adenocarcinoma (Caco-2) cell line was obtained from the American Type Culture Collection. The human colon adenocarcinoma mucus-secreting (HT29-MTX) cell line was obtained from the European Collection of Cell Cultures. Cells were cultured in Dulbecco's Modified Eagle Medium with GlutaMAX (DMEM) (Gibco, Waltham MA, USA) supplemented with $10 \%$ fetal calf serum (Gibco), 1\% penicillin-streptomycin (Sigma) and 1\% non-essential amino acids (Gibco). The cells were subcultured every 2-3 days. For the translocation experiments, the cells were seeded at a density of 40,000 cells per $\mathrm{cm}^{2}$ in Transwell polyester inserts $(3 \mu \mathrm{m}$ pore size, $1.12 \mathrm{~cm}^{2}$ surface area, Corning, Amsterdam, The Netherlands), with a 3:1 ratio of Caco-2/HT29-MTX cells and grown for 21 days. During this period of growing the medium was refreshed every 2-3 days. To assess the integrity of the cell barrier the TEER (Trans Epithelial/Endothelial Electrical Resistance) values were measured using a MERSSTX01 electrode (Millipore, USA) connected to the Millicell ERS-2 Epithelial Volt-Ohm meter (Millipore). Only inserts with initial TEER values above $200 \Omega \mathrm{cm}^{2}$ were used [47]. After the exposure, TEER values of the microplastic exposed wells were not lower than the TEER values detected in control wells. In addition fluorescein transport was studied after exposure to the microplastics. For this fluorescein (Sigma), was added apically to the inserts at a concentration of $10 \mu \mathrm{M}$ in $\mathrm{HBSS}(500 \mu \mathrm{l} /$ insert). Following $1 \mathrm{~h}$ incubation at $37^{\circ} \mathrm{C}$ basolateral samples were collected. And analysed for fluorescence at $494 / 525 \mathrm{~nm}$, and compared to a calibration curve. Fluorescence translocation following exposure of cell layers was not increased compared to that in control wells (i.e. $6.1 \% \pm 1.1$ and $5.6 \pm 1.3$ respectively) and in line with previous observations in our laboratory [48].

The cells in these inserts were exposed for $24 \mathrm{~h}$ to the exposure medium which was prepared from the unfiltered fluids that resulted from the simulated in vitro digestion. For the final exposure chyme samples were diluted towards non-cytotoxic chyme concentrations as shown before [46, 49]. These samples were vortexed and diluted 10 times with a mixture of HBSS containing 30 mg BSA and $0.01 \mathrm{ml}$ penicillin and streptomycin $/ \mathrm{ml}$ HBSS to keep the sample sterile. $0.5 \mathrm{ml}$ of the exposure medium was added apically to the inserts with cells. 1.5 $\mathrm{ml}$ of a mixture of $10 \mathrm{mg}$ BSA and $0.01 \mathrm{ml} \mathrm{P/S} / \mathrm{ml} \mathrm{HBSS}$ was added to the basolateral compartment per insert.

Typically, $75 \mu \mathrm{l}$ subsamples were taken at the basolateral compartment at $\mathrm{t}=0$ and $\mathrm{t}=24 \mathrm{~h}$ while the plate was kept in the incubator at $37^{\circ} \mathrm{C}$ between these time points. The samples were stored in glass vials at $-80^{\circ} \mathrm{C}$ before further analysis. To determine the organic chemicals that were translocated, the basolateral samples were extracted with $200 \mu \mathrm{l}$ of ethyl acetate after addition of the internal standard ${ }^{13} \mathrm{C}-\mathrm{PCB}-209$. The extract was dried with sodium sulphate and $100 \mu \mathrm{l}$ of the extract was analysed with GCxGC-TOFMS as described above. For identification, a dedicated library was used that was compiled from the compounds identified in the in vitro digestion samples. To determine the elements that were translocated during the experiment, a $200 \mu \mathrm{l}$ aqueous subsample was diluted to $4 \mathrm{~mL}$ and acidified with nitric acid to $3 \% \mathrm{HNO}_{3}$ and after addition of rhodium as the internal standard analysed with ICP-MS as described above.

\section{Chemical analysis}

For the identification and quantification of chemicals that are associated with the microplastics, chemical analyses were performed. For the determination of the organic compounds sample extracts were analysed with twodimensional gas chromatography combined with time-offlight mass spectrometry (GCxGC-TOFMS). The GCxGC-TOFMS was a combination of a Pegasus-III TOFMS system (LECO, Corporation, St. Joseph, USA) and an Agilent 6890 gas chromatograph (GC, Agilent technologies, Santa Clara, USA) equipped with CIS-4 PTV injector (Gerstel, town, country). The GC was equipped with a $10 \mathrm{~m} \times 0,25 \mathrm{~mm}$, inner diameter $0,25 \mu \mathrm{m}$, Rtx-Cl 
Pesticide column (Restek, Mülheim an der Ruhr, Germany) in the first dimension and a $1 \mathrm{~m} \times 0.1 \mathrm{~mm}$, film thickness $0.1 \mu \mathrm{m}$ BPX-50 column (SGE, Austin, USA) in the second dimension. The temperature program was as follows; 1st dimension $60^{\circ} \mathrm{C}(2 \mathrm{~min})$ to $320^{\circ} \mathrm{C}(6 \mathrm{~min})$ increasing the temperature with $15^{\circ} / \mathrm{min}$; 2nd dimension $125^{\circ} \mathrm{C}$ (5 min) to $270^{\circ} \mathrm{C}$ with increasing the temperature $15^{\circ} / \mathrm{min}$; to $345^{\circ} \mathrm{C}$ with $25^{\circ} / \mathrm{min}$ and to $365^{\circ} \mathrm{C}$ (7 min) with $15^{\circ} / \mathrm{min}$ ). A two-step modulator cooled with liquid nitrogen was used and the run time in the second dimension was $4.5 \mathrm{~s}$. The scan speed was $200 \mathrm{scans} / \mathrm{s}$ with a mass range of $50-1000 \mathrm{~m} / \mathrm{z}$. Peaks were identified using a dedicated in house library database that contained 650 compounds (mainly environmental contaminants) and a NIST database. Only identifications of peaks for which the correlation between the mass spectrum of the unknown component in the chromatogram and the reference spectrum in the database is $>80 \%$ were accepted. Compounds identified with the dedicated library database were quantitatively detected while for the other compounds the detection was semi-quantitative based on an averaged response factor.

For the determination of elements aqueous samples or sample digests are analysed with inductively coupled plasma mass spectrometry (ICP-MS). The ICP-MS was a Perkin Elmer 350D equipped with an autosampler and a conical glass concentric nebulizer and operated at an RF power of $1600 \mathrm{~W}$. Rhodium was added as an internal standard and data acquisition was performed in the scanning mode with KED (helium $4.1 \mathrm{~mL} / \mathrm{min}$ ) using $\mathrm{m} /$ $\mathrm{z}$ values in the range of $\mathrm{m} / \mathrm{z} 7$ to 238 for the selected elements. Quantification was based on an external standard containing 70 individual elements.

\section{Data analysis}

GraphPad Prism 5 was used to prepare the graphs. We assessed the ToxCast database [50] online, selected the end-points from the high-throughput assay matching our compounds and extracted the respective activity values $50\left(\mathrm{AC}_{50}\right.$, concentration at $50 \%$ of maximum activity), and the indicated Adverse Outcome Pathways. The IARC database [51] was also assessed online.

\section{Results and discussion}

Chemical toxicity following ingestion of microplastics may occur as they can act as vectors to transfer associated chemicals into the body [52]. Using sensitive GCMS and ICP-MS we here show firstly that 68 chemicals leached from the microplastics using stringent chemical extraction (Tables 3 and 4) and secondly that some of these chemicals can be released in vitro under conditions representing the luminal content of the human digestive tract (i.e. chyme). For this the in vivo digestive tract conditions were simulated using an in vitro digestion model and the concentration of chemicals in the chyme were quantified. Next the potential translocation of the chemicals in the chyme was evaluated using the in vitro Caco-2 Transwell intestinal epithelial cell model. Of the detected chemicals, 58 chemicals were present in the ToxCast database of which 31 were screened (to some extent). From those we identified $\mathrm{AC}_{50} \mathrm{~s}$ from high-throughput assays targeting endocrine activity. We observed that estrogenic potency is the most often involved Adverse Outcome Pathway (AOP) of the chemicals listed in the ToxCast database. Next to the analysis of the sample for the presence of organic chemicals, samples were analysed for the presence of elements using ICP-MS. In total 28 elements were identified leaching from the microplastics. More details of the chemical presence will be discussed per microplastics type.

\section{Environmental microplastics $<1 \mathrm{~mm}$}

The environmental microplastics originate from plastic litter collected on Dutch beaches that was subsequently grinded down to two size fractions (i.e. $1 \mathrm{~mm}$ and $3 \mathrm{~mm}$ ) [9]. In the chemical leachate of the $1 \mathrm{~mm}$ environmental microplastics 42 organic compounds were identified with typical flame retardants and phthalates being the most prominent (see Fig. 2). Although low concentrations of hexabromocyclododecane and pentabromocyclododecane were found, the major flame retardants were organophosphates with a highest leachate concentration of 7.6 $\mathrm{mg} / \mathrm{kg}$ for tris (1-chloro-2-propyl)phosphate. Other prominent flame retardants were tri-tolylphosphates and bis (3-chloro-1-propyl)(1-chloro-2-propyl)phosphate. Of the phthalates bis (2-ethylhexyl) and di-isooctyl phthalate were identified as the most prominent with the highest concentration being $8.9 \mathrm{mg} / \mathrm{kg}$. Another prominent phthalate was identified as phthalic acid, hex-3-yl nonyl ester with a concentration of $6.1 \mathrm{mg} / \mathrm{kg}$. A number of other compounds were identified with 2,4-di-tert.butyl phenol being the most prominent with a concentration of $6.7 \mathrm{mg} / \mathrm{kg}$. Finally, a series of polycyclic aromatic hydrocarbons $(\mathrm{PAH})$ were identified in concentrations ranging from $0.9 \mathrm{mg} / \mathrm{kg}$ for naphthalene to $0.1 \mathrm{mg} / \mathrm{kg}$ for chrysene. Some differences with the previous chemical analysis are noted, but the for the most abundant chemicals we confirm the previous analyses [9].

After the in vitro digestion of the $1 \mathrm{~mm}$ environmental microplastics 27 organic compounds were identified in the chyme (Fig. 2). The flame retardants and phthalates identified in the chyme sample were also observed in the chemical leachates. In fact, the concentrations of the chlorinated organophosphates were in general comparable to those in the chemical leachates, probably because they are relatively water soluble and are therefore easily released during the in vitro digestion into the chyme. 
Table 3 Overview of all identified plastic associated chemicals and in which type of microplastics sample they were detected

\begin{tabular}{|c|c|c|c|c|c|c|c|}
\hline \multirow[b]{2}{*}{ Compound } & \multirow[b]{2}{*}{ CAS nr } & \multirow[b]{2}{*}{ Present in sample type } & \multirow{2}{*}{$\begin{array}{l}\text { Present } \\
\text { in } \\
\text { Toxcast }\end{array}$} & \multicolumn{4}{|c|}{ AC50 (uM) } \\
\hline & & & & AHR & $\begin{array}{l}\text { OS } \\
\text { (NFE2L2) }\end{array}$ & AR & $\begin{array}{l}\text { ER } \\
\text { (ESR1) }\end{array}$ \\
\hline \multicolumn{8}{|l|}{ Flame retardants } \\
\hline $\begin{array}{l}\text { Bis(1-chloro-2-propyl)-3-(3- } \\
\text { chloropropoxy)propylphosphate }\end{array}$ & $\begin{array}{l}137,888-37- \\
0\end{array}$ & ENV-1, ENV-3 & no & & & & \\
\hline Bis(3-chloro-1-propyl)(1-chloro-2-propyl)phosphate & $\begin{array}{l}137,888-35- \\
8\end{array}$ & ENV-1, ENV-3 & yes & n.d. & n.d. & n.d. & n.d. \\
\hline Hexabromocyclododecane & $25,637-99-4$ & ENV-1, ENV-3 & yes & n.d. & n.d. & n.d. & n.d. \\
\hline Pentabromocyclododecane & $26,657-83-0$ & ENV-1, ENV-3 & yes & n.d. & n.d. & n.d. & n.d. \\
\hline Triethylphosphate & $78-40-0$ & ENV-1, & yes & n.d. & n.a. & n.a. & 90.5 \\
\hline Triisobutylphosphate & $126-71-6$ & ENV-1, ENV-3, PA, PVC & yes & 78.9 & n.a. & n.a. & 43.8 \\
\hline Tri-m-tolylphosphate & $563-04-2$ & ENV-1, & yes & n.a. & 18.2 & n.a. & 57.1 \\
\hline Tri-o-tolylphosphate & 78-30-8 & ENV-1, ENV-3,PS & yes & 285 & 13.8 & 23.7 & 1.82 \\
\hline Triphenylphosphate & $115-86-6$ & ENV-1, ENV-3 & yes & n.d. & 18.4 & 25.3 & 7.31 \\
\hline Tri-p-tolylphosphate & $78-32-0$ & ENV-1, ENV-3 & yes & n.d. & n.d. & n.d. & n.d. \\
\hline Tris(1-chloro-2-propyl)phosphate & $13,674-84-5$ & $\begin{array}{l}\text { ENV-1, ENV-3, PA, PE, PP-1, PP-2, PS, } \\
\text { PVC }\end{array}$ & yes & n.d. & n.d. & n.a. & n.a. \\
\hline Tris(2-chloroethyl)phosphate & $115-96-8$ & ENV-1, ENV-3 & yes & n.d. & n.d. & n.a. & n.a. \\
\hline Tris(2-chloropropyl)phosphate & 6145-73-9 & ENV-1, ENV-3,PA, PE, PP-1, PP-2, PVC & yes & n.a. & n.a. & n.a. & n.a. \\
\hline \multicolumn{8}{|l|}{ Plasticiser } \\
\hline 1,4-Benzenedicarboxylic acid, bis(2-ethylhexyl) ester & $6422-86-2$ & ENV-1, ENV-3 & yes & 68.9 & n.d. & n.a. & n.a. \\
\hline Bis(2-ethylhexyl) phthalate & $117-81-7$ & $\begin{array}{l}\text { ENV-1, ENV-3, PA, PE, PET, PP-1, PP-2, } \\
\text { PS, PVC }\end{array}$ & yes & n.d. & n.d. & 52.1 & 59.5 \\
\hline Dibutyl phthalate & $84-74-2$ & ENV-1, ENV-3, PA, PP-1, PP-2, PVC & yes & n.d. & 50.9 & 58 & 32.8 \\
\hline Diisooctyl adipate & $1330-86-5$ & ENV-1, & yes & n.d. & n.d. & 3.38 & n.d. \\
\hline Diisooctyl phthalate & $27,554-26-3$ & ENV-1, ENV-3 & yes & n.d. & n.d. & n.d. & n.d. \\
\hline Phthalic acid, 2-ethylbutyl nonyl ester & n.a. & ENV-3, & no & & & & \\
\hline Phthalic acid, 6-methylhept-2-yl nonyl ester & n.a. & ENV-1, & no & & & & \\
\hline Phthalic acid, di(2-propylpentyl) ester & $70,910-37-1$ & PA, PET, PP-1, PP-2, PVC & yes & n.d. & n.d. & n.d. & n.d. \\
\hline Phthalic acid, di (oct-3-yl) ester & n.a. & ENV-3, PE & no & & & & \\
\hline $\begin{array}{l}\text { Phthalic acid, hept-3-yl nonyl ester/phthalic acide hexyl } \\
\text { nonyl ester }\end{array}$ & $88,216-56-2$ & ENV-1, ENV-3 & yes & n.d. & n.d. & n.d. & n.d. \\
\hline Phthalic acid, hept-4-yl isobutyl ester & n.a. & PA, PVC & no & & & & \\
\hline $\begin{array}{l}\text { Phthalic acid, nonyl 2-propylpentyl ester/ phthalic } \\
\text { dinonyl ester }\end{array}$ & 84-76-4 & ENV-1, ENV-3 & yes & n.d. & n.d. & 3.4 & n.d. \\
\hline 2-Ethylhexyl methyl isophthalate & $\begin{array}{l}2,135,327- \\
80-7\end{array}$ & ENV-1, & yes & n.d. & n.d. & n.d. & n.d. \\
\hline Tributyl acetylcitrate & $693-71-0$ & PET & yes & n.d. & n.d. & n.d. & n.d. \\
\hline \multicolumn{8}{|l|}{ Monomers and other compounds } \\
\hline (Z)-(Z)-Hex-3-en-1-yl 2-methylbut-2-enoate & $84,060-80-0$ & ENV-1, & no & & & & \\
\hline 1,15-Pentadecanediol & $14,722-40-8$ & PE & yes & n.d. & n.d. & n.d. & n.d. \\
\hline $\begin{array}{l}\text { 1,8-Diazacyclotetradecane-2,9-dione (=nylon-6 cyclic } \\
\text { oligomer) }\end{array}$ & $56,403-09-9$ & PA & yes & n.d. & n.d. & n.d. & n.d. \\
\hline 1H-Imidazole & $288-32-4$ & ENV-1 & yes & n.d. & n.d. & n.d. & n.d. \\
\hline 2,4-Di-tert-butylphenol & $96-76-4$ & ENV-1, ENV-3 & yes & n.d. & 36.9 & 12.4 & 41 \\
\hline 2-Ethyl-1-hexanol & $104-76-7$ & ENV-1, & yes & n.d. & n.d. & n.d. & n.d. \\
\hline 3-(Benzoylthio)-2-methylpropanoic acid & $74,431-50-8$ & ENV-3, & no & & & & \\
\hline 3,3-Dimethylheptanoic acid & $67,061-30-7$ & PVC & no & & & & \\
\hline 3,5-di-tert-Butyl-4-hydroxybenzaldehyde & $1620-98-0$ & ENV-1, & yes & n.d. & n.d. & n.d. & n.d. \\
\hline
\end{tabular}


Table 3 Overview of all identified plastic associated chemicals and in which type of microplastics sample they were detected (Continued)

\begin{tabular}{|c|c|c|c|c|c|c|c|}
\hline \multirow[b]{2}{*}{ Compound } & \multirow[b]{2}{*}{ CAS nr } & \multirow[b]{2}{*}{ Present in sample type } & \multirow{2}{*}{$\begin{array}{l}\text { Present } \\
\text { in } \\
\text { Toxcast }\end{array}$} & \multicolumn{4}{|c|}{ AC50 (uM) } \\
\hline & & & & AHR & $\begin{array}{l}\text { OS } \\
\text { (NFE2L2) }\end{array}$ & AR & $\begin{array}{l}\text { ER } \\
\text { (ESR1) }\end{array}$ \\
\hline 3-tert-Butyl-4-hydroxyanisole & $121-00-6$ & PVC & yes & n.d. & 42.4 & 13.1 & 2.46 \\
\hline Alkylated benzenes & n.a. & PS & no & & & & \\
\hline Benzaldehyde & $100-52-7$ & PS & yes & n.d. & n.d. & n.d. & n.d. \\
\hline Benzene, 1-(chloromethyl)-2-methyl & $552-45-4$ & PVC & yes & n.d. & n.d. & n.d. & n.d. \\
\hline Benzene, 1,3-bis(1,1-dimethylethyl)- & $1014-60-4$ & ENV-1, ENV-3 & yes & n.d. & n.d. & n.d. & n.d. \\
\hline Benzoic acid, octyl ester & $94-50-8$ & PVC & yes & n.d. & n.d. & n.d. & n.d. \\
\hline Borane, diethyl (decyloxy) & $25,015-63-8$ & PP-1 & yes & n.d. & n.d. & n.d. & n.d. \\
\hline Butanedioic acid, dimethyl ester & $106-65-0$ & PVC & yes & 1.49 & n.d. & n.d. & n.d. \\
\hline Butylated Hydroxytoluene & $128-37-0$ & ENV-1, ENV-3 & yes & n.d. & 49.2 & 0.112 & 21 \\
\hline Caprolactam (=nylon-6 monomer) & $105-60-2$ & PA & yes & n.d. & n.d. & 68 & 30.8 \\
\hline Hexanedioic acid, bis(2-ethylhexyl) ester & $103-23-1$ & PVC & yes & n.d. & n.d. & 93 & 10.9 \\
\hline Hexanedioic acid, bis(2-methylpropyl) ester & $141-04-8$ & ENV-3, & yes & n.d. & n.d. & n.d. & 8.25 \\
\hline Hexanedioic acid, dimethyl ester & $627-93-0$ & PVC & yes & n.d. & 60.6 & n.d. & n.d. \\
\hline Linoelaidic acid & $506-21-8$ & ENV-1, & yes & n.d. & n.d. & n.d. & n.d. \\
\hline n-Hexadecanoic acid & $57-10-3$ & PP-1, PP-2 & yes & n.d. & n.d. & n.d. & 7.46 \\
\hline Octadecane, 1-isocyanato- & $112-96-9$ & PA & yes & n.d. & n.d. & n.d. & n.d. \\
\hline Octadecanoic acid & $57-11-4$ & PP-1, PP-2 & yes & n.d. & n.d. & 12.1 & 2.3 \\
\hline Octanal, 2-(phenylmethylene)- & $101-86-0$ & ENV-1, & yes & 56.6 & 30.9 & 2.97 & 35.5 \\
\hline Oxalic acid, allyl butyl ester & $91,915-04-7$ & PVC & yes & n.d. & n.d. & n.d. & n.d. \\
\hline Pentanedioic acid, dimethyl ester & $1119-40-0$ & PVC & yes & n.d. & n.d. & n.d. & n.d. \\
\hline Styrene & $100-42-5$ & PS & yes & n.d. & n.d. & n.d. & n.d. \\
\hline $\begin{array}{l}\text { Tetrazolo[1,5-b]1,2,4-triazine, 5,6,7,8-tetrahydro-6,7- } \\
\text { dimethyl- }\end{array}$ & $\begin{array}{l}384,814-90- \\
8\end{array}$ & PA & no & & & & \\
\hline \multicolumn{8}{|l|}{ Environmental contaminants } \\
\hline Acenaphtene & $83-32-9$ & ENV-1, ENV-3 & yes & n.d. & n.d. & n.d. & 24.9 \\
\hline Acenaphtylene & 208-96-8 & ENV-1, & yes & 91.5 & n.d. & n.d. & n.d. \\
\hline Antracene & $120-12-7$ & ENV-1, PP-1, PP-2 & yes & n.d. & n.d. & 22.3 & 24.1 \\
\hline Benz [a]anthracene & $56-55-3$ & ENV-1, ENV-3 & yes & n.d. & 1.17 & 5.77 & 1.45 \\
\hline Chrysene & 218-01-9 & ENV-1, ENV-3 & yes & 7.86 & 28.2 & n.d. & n.d. \\
\hline Fluoranthene & $206-44-0$ & ENV-1, ENV-3 & yes & 67 & n.d. & 5.83 & 46.2 \\
\hline Fluorene & $86-73-7$ & ENV-1, ENV-3, PE & yes & n.d. & 70.1 & 18.1 & 0.436 \\
\hline Naphtalene & $91-20-3$ & ENV-1, ENV-3, PP-1, PP-2, PVC & yes & n.d. & n.d. & n.d. & 0.655 \\
\hline Phenanthrene & $85-01-8$ & ENV-1, ENV-3,PP-1, PP-2 & yes & n.d. & 20.7 & 0.002 & n.d. \\
\hline Pyrene & $129-00-0$ & ENV-1, ENV-3 & yes & n.d. & 3.32 & n.d. & n.d. \\
\hline
\end{tabular}

Legend: $E N V-1$ environmental microplastic $<1 \mathrm{~mm}$, environmental microplastic $<3 \mathrm{~mm}, P A$ polyamide, $P E$ Polyethylene, $P E T$ Polyethylene terephthalate, $P P-1 / P P-2$ Polypropylene, PS Polystyrene, PVC Polyvinylchloride,

AHR Aryl hydrocarbon receptor, OS oxidative stress: activation of NFE2L2 (Nuclear factor erythroid 2-related factor 2) gene, $A R$ activation of androgen receptor, ER estrogenic activity, activation of Estrogenic receptor 1, n.d. not determined, n.a. not available

The alkyl- and arylphosphate flame retardants were also present in the chyme but in much lower concentrations than in the chemical leachates (on average 20\%). The far more apolar hexabromocyclododecane and pentabromocyclododecane were not detected in the chyme. Phthalates were also found in the in chyme and may therefore become available for uptake via the intestinal epithelium.
However, the observed concentrations in chyme were about half of those in the chemical leachates. Of the polycyclic aromatic hydrocarbons only naphthalene was identified in the chyme.

Only a few compounds were detected in the basolateral fluids of the translocation study (Fig. 2). Again, these were mainly the chlorinated organophosphate 
Table 4 Overview of all identified metals and in which microplastics sample they were detected

\begin{tabular}{|c|c|c|c|c|c|}
\hline Name & CAS nr & Present in sample & $\begin{array}{l}\text { chronic oral PoD } \\
\text { ( } \mathrm{mg} / \mathrm{kg} \text { day) }\end{array}$ & Point of Departure & Species \\
\hline $\mathrm{Li} 7$ & $7439-93-2$ & ENV-1, ENV-3, PA, PE, PET, PP-1, PP-2, PVC & 1.2 & NOAEL & human \\
\hline Ti 47 & $7440-32-6$ & ENV-1, ENV-3, PA, PE, PP-1, PP-2, PS, PVC & 24,000 & NOEL & rat \\
\hline$\vee 51$ & $7440-62-2$ & ENV-1, ENV-3, PA, PE, PP-1, PVC & 0.22 & NOAEL & rat \\
\hline Cr 52 & $7440-47-3$ & ENV-1, ENV-3, PA, PE, PVC & 1216 & NOAEL & rat \\
\hline Mn 55 & $7439-96-5$ & ENV-1, ENV-3, PA, PE, PET, PP-1, PP-2, PS,PVC & 0.14 & NOAEL & human \\
\hline Fe 56 & 7429-89-6 & ENV-1, ENV-3, PA, PE, PP-1 & 1 & LOAEL & human \\
\hline Co 59 & $7440-48-4$ & ENV-1, ENV-3, PA, PE, PET & 1 & LOAEL & human \\
\hline Ni 60 & $7440-02-0$ & ENV-1, ENV-3 & 5 & NOAEL & rat \\
\hline Cu 65 & $7440-50-8$ & ENV-1, ENV-3, PA, PE,PS & 5.3 & LOAEL & human \\
\hline Zn 66 & $7440-66-6$ & ENV-1, ENV-3, PVC & 0.9 & NOAEL & human \\
\hline As 75 & $7440-38-2$ & ENV-1, ENV-3, PVC & 0.0009 & NOAEL & human \\
\hline Se 78 & $7782-49-2$ & ENV-1, ENV-3 & 0.015 & NOAEL & human \\
\hline $\mathrm{Rb} 85$ & 7440-17-7 & ENV-1, ENV-3, PVC & 5.3 & LOAEL & not mentioned \\
\hline $\operatorname{Sr} 88$ & $7440-24-6$ & ENV-1, ENV-3, PA, PE, PP-1, PVC & 60 & NOAEL & human \\
\hline $\operatorname{Zr} 91$ & $7440-67-7$ & ENV-1, ENV-3, PA, PE, PET, PP-1, PP-2, PVC & 3156 & NOAEL & rat \\
\hline Mo 98 & 7439-98-7 & ENV-1, ENV-3, PA, PE, PP-1, PVC & 5 & NOAEL & human \\
\hline Ag 107 & $7440-22-4$ & ENV-1, ENV-3, PA, PE, PVC & 0.014 & LOAEL & not mentioned \\
\hline Cd 111 & $7440-43-9$ & ENV-1, ENV-3 & 0.0003 & NOAEL & human \\
\hline Sn 118 & $7440-31-5$ & ENV-1, ENV-3, PE, PET, PS, PVC & 30 & NOAEL (subacute) & human \\
\hline Sb 121 & $7440-36-0$ & ENV-1, ENV-3, PE, PET, PP-1 & 0.06 & NOAEL (subacute) & human \\
\hline Ba 138 & $7440-39-3$ & ENV-1, ENV-3, PA, PE, PP-1 & 0.21 & NOAEL & human \\
\hline Ce 140 & $7440-46-2$ & ENV-1, ENV-3, PA, PP-1, PVC & n.d. & n.d. & n.d. \\
\hline Ta 181 & $7440-25-7$ & ENV-1, PA, PET, PS & n.d. & n.d. & n.d. \\
\hline W 184 & $7440-33-7$ & ENV-1, PA, PE & 2 & NOAEL & rat \\
\hline $\operatorname{Re} 187$ & 7440-15-5 & ENV-1, PP-1 & n.d. & n.d. & n.d. \\
\hline Tl 205 & $7440-28-0$ & ENV-1, ENV-3, PA, PET,PP-1 & 0.04 & NOAEL & not mentioned \\
\hline $\mathrm{Pb} 208$ & 7439-92-1 & ENV-1, ENV-3, PA, PE,PP-1, PS, PVC & 0.5 & BMDL01 & human \\
\hline Bi 209 & 7440-69-9 & ENV-1, ENV-3, PA, PE,PP-2, PS & 25 & NOAEL & rat \\
\hline
\end{tabular}

For each metal it is indicated if a point of departure (PoD) was listed in the TOXCAST database. ENV-1 environmental microplastic $<1$ mm, environmental microplastic $<3 \mathrm{~mm}, P A$ polyamide, $P E$ Polyethylene, $P E T$ Polyethylene terephthalate, $P P-1 / P P-2$ Polypropylene, $P S$ Polystyrene, $P V C$ Polyvinylchloride

flame retardants bis (3-chloro-1-propyl)(1-chloro-2-propyl) phosphate, tris (1-chloro-2-propyl) phosphate and tris (2-chloropropyl)phosphate. The concentrations of these flame retardants in the chyme and after in vitro translocation in the basolateral fluids were in the range of 0.1 to $0.9 \mathrm{mg} / \mathrm{kg}$. Of the phthalates, di-isooctyl phthalate was found in a relatively high concentration of 2.2 $\mathrm{mg} / \mathrm{kg}$ in the basolateral fluids after the in vitro translocation experiment while other phthalates (mainly bis (2-ethylhexyl)phthalate) were also detected but at concentrations $<1 \mathrm{mg} / \mathrm{kg}$. Of the PAHs only naphthalene was found in the basolateral fluids, in a concentration of $0.1 \mathrm{mg} / \mathrm{kg}$. The in vitro translocation experiments were, obviously, performed in plastic Transwells, therefore absorption and adsorption of chemicals to the plastic material need to be considered. The equilibrium between chemicals in medium and absorbed to plastic take several hours or days for high $\log \mathrm{K}_{\mathrm{ow}}$ chemicals, and several days for neutral chemicals. As recently reviewed, absorption rates of chemicals to plastics are slower than adsorption rates of chemical to plastics [53]. These processes might result in an underestimation of the chemicals present after in vitro translocation.

A large number of elements were also found in the 1 $\mathrm{mm}$ environmental microplastics, in total 28 ranging from lithium to bismuth (Fig. 3). It should be kept in mind that, different from the organic compounds, these elements were not leached from the microplastics but liberated after a complete digestion of the plastic matrix so the concentrations will be accordingly higher. Highest concentrations were found for iron $(2099 \mathrm{mg} / \mathrm{kg})$ and barium $(1544 \mathrm{mg} / \mathrm{kg})$. Barium sulfate is being used as a 


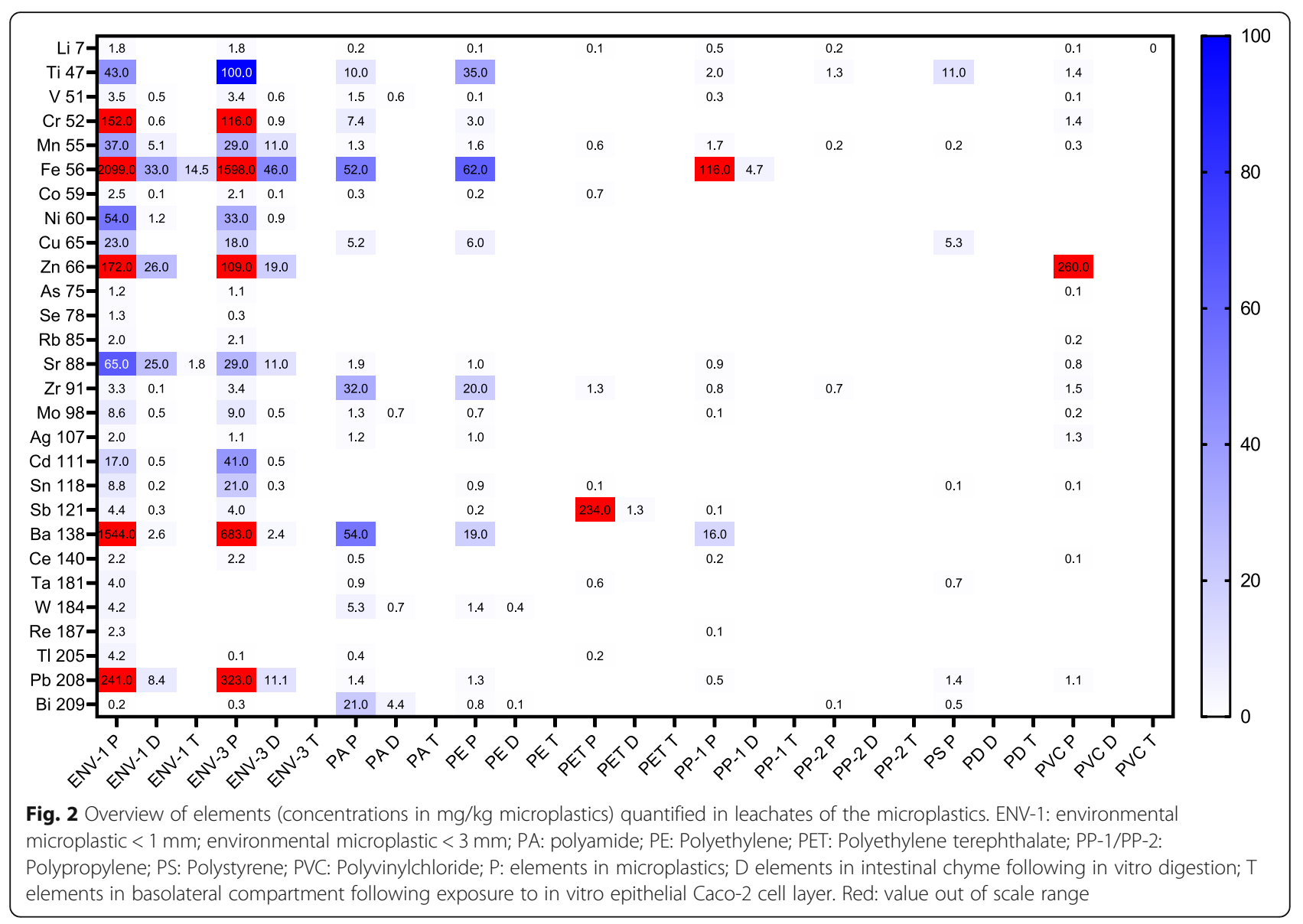

filler in the plastic industry, for instance in the production of polyethylene sewage tubes and may therefore be present in this sample. Iron has been found before in high concentrations in plastic waste from electrical and electronic equipment [54]. Relatively high concentrations were also found for lead, zinc and chromium.

In the in vitro digestion only a limited number of elements, 15 of the 28 observed in the chemical analysis, are present in concentrations which are in general much lower than in the plastic chemical digest (Fig. 3). Highest concentrations were found for iron $(33 \mathrm{mg} / \mathrm{kg})$, zinc $(26$ $\mathrm{mg} / \mathrm{kg}$ ) and strontium $(25 \mathrm{mg} / \mathrm{kg})$. Zinc is used in the plastic industry in the form of zinc stearate ("zinc soap"), a release agent and lubricant $[55,56]$, and may therefore be found in this sample and in the bioaccessible fraction in a relatively high concentration. No information was found on the origin of strontium in the chemical digest and its relatively high concentration in the bioaccessible fraction.

Only two elements were found to translocate across the Caco-2 cell layer in vitro. These were iron, which was present in high concentrations in the chemical digest and in the in vitro digestion, and strontium which was also present in relatively high concentrations in the in vitro digestion (Fig. 3). Concentrations of iron and strontium in the basolateral fluids were 14.5 and $1.8 \mathrm{mg} /$ $\mathrm{kg}$, respectively.

\section{Environmental microplastics $<3 \mathrm{~mm}$}

The results for the $3 \mathrm{~mm}$ environmental microplastics are comparable to that of the $1 \mathrm{~mm}$ microplastic material which is to be expected since it is the same material only grinded to a different particle size. In total 33 different compounds were identified and as before the flame retardants and phthalates are the most prominent (Fig. 2). In general, the concentrations are somewhat lower than for the $1 \mathrm{~mm}$ material, as to be expected because of the smaller surface area to volume ratio. Some other compounds like 2,4-di-tert.butyl phenol and butylated hydroxytoluene were also found in this sample. The PAHs were also found in this sample but, as with the others, in somewhat lower concentrations.

The flame retardants, especially the chlorinated organophosphates, and the phthalates were also found in the in vitro digestion in concentrations which were about half of the concentrations in the chemical leachate (Fig. 2). Of the PAHs only naphthalene was found in a concentration of $0.4 \mathrm{mg} / \mathrm{kg}$ which was equal to what was 


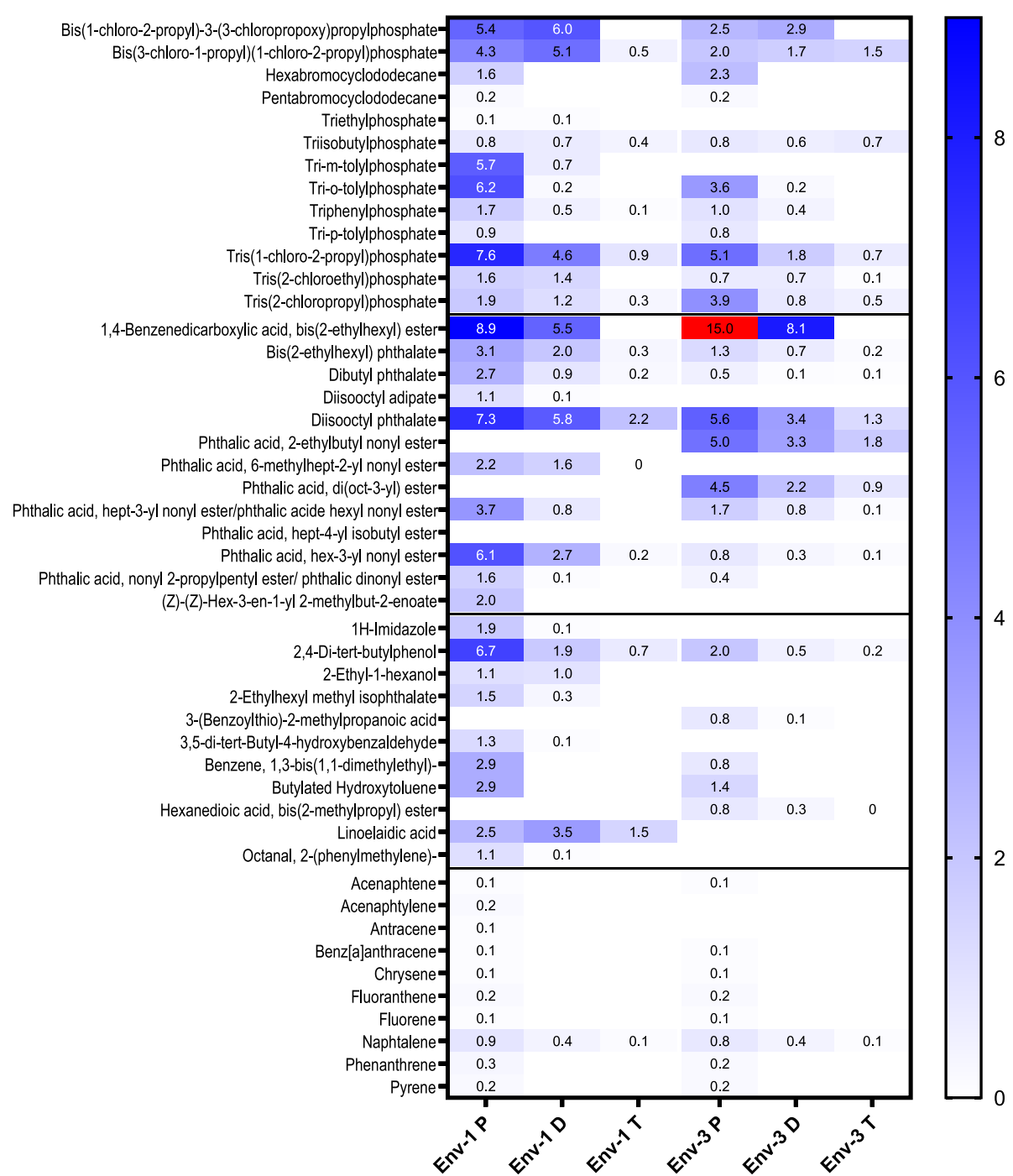

Fig. 3 Overview of chemicals (concentrations in $\mathrm{mg} / \mathrm{kg}$ microplastics) quantified in leachates of the environmental microplastics. ENV-1: environmental microplastic $<1 \mathrm{~mm}$; environmental microplastic $<3 \mathrm{~mm}$; P:chemicals in leachate from microplastics; $D$ chemicals in intestinal chyme following in vitro digestion; T chemicals in basolateral compartment following exposure to in vitro epithelial Caco-2 cell layer. Red: value out of scale range

found in the in vitro digestion of the $1 \mathrm{~mm}$ microplastics.

Only a limited number of compounds translocated across the Caco-2 cell layer in vitro (Fig. 2). As for the 1 $\mathrm{mm}$ microplastics this was limited to the chlorinated organophosphates and a number of phthalates. Typical concentrations of compounds following in vitro digestion and basolateral fluids ranged from 0.1 to $1.8 \mathrm{mg} / \mathrm{kg}$. Of the PAHs on naphthalene was found in a concentration of $0.1 \mathrm{mg} / \mathrm{kg}$.

A total number of 25 elements were found after chemical digestion of the $3 \mathrm{~mm}$ environmental microplastics (Fig. 3). The nature and concentration of these elements is comparable with that of the $1 \mathrm{~mm}$ microplastics with iron, barium and lead as the highest. Differences between the 1 and $3 \mathrm{~mm}$ material probably originate from the inhomogeneity of the microplastic materials.

The results for the in vitro digestion are also comparable with that for the $1 \mathrm{~mm}$ material (Fig. 3). 13 of the 25 elements were found and iron, zinc and strontium are found in the highest concentration. It should be noted that the concentration of lead, $11 \mathrm{mg} / \mathrm{kg}$, in this sample was comparable with that of strontium. Lead is sometimes present in paints which are used as surface coatings for plastic materials and may therefore be found in the investigated microplastics [57]. For the same reason lead may also end up in recycled plastic materials. In the in vitro translocation experiment no elements were detected in the basolateral fluids (Fig. 2). Taking into account the dilutions in the translocation 
experiment the limit of detection for the elements is 0.3 $\mathrm{mg} / \mathrm{kg}$.

\section{Polyamide microplastics}

For these and the other pre-production powders, the source of the chemicals detected in our chemical leachates (and chyme and following translocation) could either be intentionally to the plastics added additives, impurities from the production process, whereas for the environmental microplastics contaminants sorbed from the ambient environment is an additional source. In the pre-production polyamide microplastics 12 compounds were identified in the chemical leachate (Fig. 4). Some flame retardants and phthalates were found but only in low concentrations in the range of 0.1 to $0.7 \mathrm{mg} / \mathrm{kg}$. Most noteworthy are the monomer caprolactam that was found in a concentration of $70 \mathrm{mg} / \mathrm{kg}$ and 1,8-diazacyclotetradecane2,9-dione, which is a nylon-6 cyclic oligomer, which was found in a concentration of $42 \mathrm{mg} / \mathrm{kg}$. Also found was 1-isocyanato octadecane and 5,6,7,8-tetrahydro6,7-dimethyl-tetrazolo [1,5-b]1,2,4-triazine in concentrations of 5.3 and $2.6 \mathrm{mg} / \mathrm{kg}$, respectively.

Most of the compounds identified in the chemical leachate were also detected in the in vitro digestion be it in lower concentrations (Fig. 4). An exception is caprolactam which is water soluble and is found in a relatively high concentration of $46 \mathrm{mg} / \mathrm{kg}$ in the in vitro digestion. Caprolactam is also found in a relative high concentration of $25 \mathrm{mg} / \mathrm{kg}$ after in vitro digestion and translocation indicating that there is a potential uptake of this compound following ingestion of polyamide microplastics. Other compounds found after in vitro digestion and translocation are a few phthalates (Fig. 4).
A surprisingly high number of 19 elements were detected in the polyamide microplastics (Fig. 2). While most concentrations are $<10 \mathrm{mg} / \mathrm{kg}$, concentrations for iron, zirconium, barium and bismuth were somewhat higher. Zirconium could be an artefact of the milling process, which was performed in a zirconium oxide jar with zirconium oxide grinding balls. Bismuth pigments have been incorporated into plastics such as polyamide as alternatives for difficult to replace lead chrome pigments which may explain the presence of bismuth [58]. Only four of these elements were also found in the in vitro digestion (Fig. 2), These are vanadium, which may be related to bismuth since it are bismuth-vanadium pigments which exert the yellow color, molybdenum, tungsten and bismuth, with the exception of bismuth in concentrations $<1 \mathrm{mg} / \mathrm{kg}$. Finally, none of the elements was detected after the translocation experiment following the in vitro digestion (Fig. 2), as mentioned before potential adsorption of the elements to the plastic labware used for the translocation experiment cannot be excluded [53].

\section{Polyethylene microplastics}

In the polyethylene microplastics 6 compounds were identified in the chemical leachate (Fig. 5). Two flame retardants, both tris (chloro-propyl) phosphates, were found but only in low concentrations of 0.2 and $0.1 \mathrm{mg} / \mathrm{kg}$. Bis (2-ethylhexyl) phthalate was found in a higher concentration of $4.2 \mathrm{mg} / \mathrm{kg}$ while phthalic acid, di (oct-3-yl) ester was found in a concentration of $0.5 \mathrm{mg} / \mathrm{kg}$. Other compounds found in low concentrations were 1,15-pentadecanediol and fluorene.

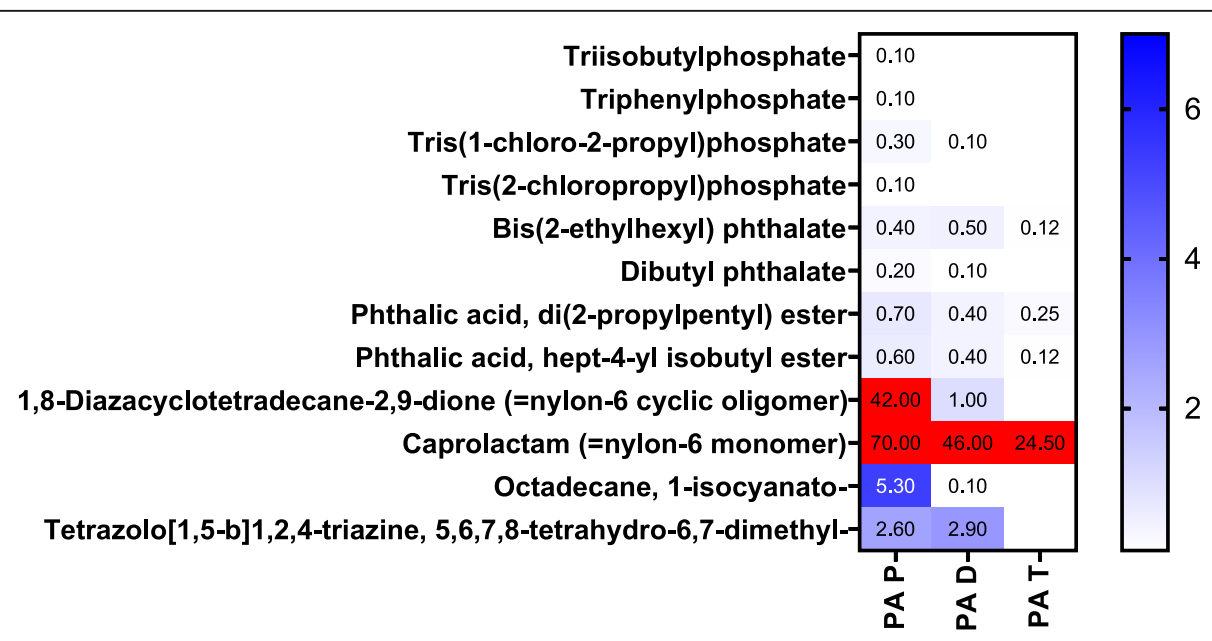

Fig. 4 Overview of chemicals (concentrations in mg/kg microplastics) quantified in leachates of the polyamide (PA) microplastics. P:chemicals in chemical leachate from microplastics; D chemicals in intestinal chyme following in vitro digestion; T chemicals in basolateral compartment following exposure to in vitro epithelial Caco-2 cell layer. Red: value out of scale range 


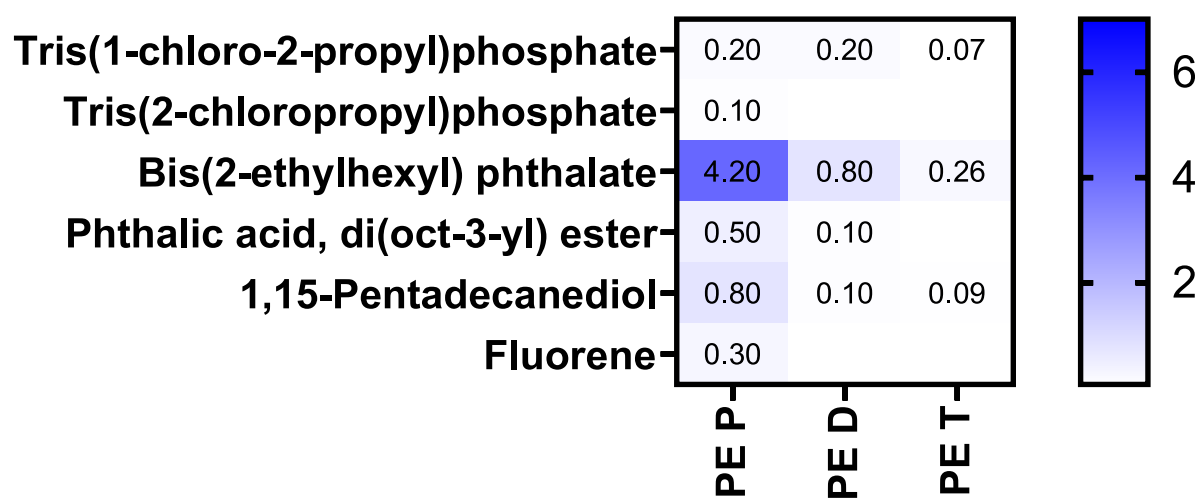

Fig. 5 Overview of chemicals (concentrations in mg/kg microplastics) quantified in leachates of the polyethylene (PE) microplastics. P:chemicals in leachate from microplastics; D chemicals in intestinal chyme following in vitro digestion; $T$ chemicals in basolateral compartment following exposure to in vitro epithelial Caco-2 cell layer

Four of the compounds identified in the chemical leachate were also detected in the in vitro digestion although in concentrations $<1 \mathrm{mg} / \mathrm{kg}$ (Fig. 5). Bis (2-ethylhexyl) phthalate, Tris (1-chloro-2-propyl) phosphate and 1,15-pentadecanediol were also found after in vitro digestion and translocation at concentrations of 0.3 and $0.1 \mathrm{mg} / \mathrm{kg}$ indicating only minor transfer from the microplastic material (Fig. 5).

In total 18 elements were detected in the polyethylene material (Fig. 2). While most were detected in concentrations $<10 \mathrm{mg} / \mathrm{kg}$, titanium, iron, zirconium and barium were detected at higher concentrations up to 62 $\mathrm{mg} / \mathrm{kg}$ for iron. The diverse presences of metals has also been observed in a study analyzing PE plastics used for different applications [59]. Titanium dioxide coated with zirconium oxides are sometimes mixed with polyethylene to increase its strength against environmental conditions which may explain its presence in this material. Only 2 of the 18 elements, tungsten and bismuth, were also detected in the chyme following in vitro digestion be it in low concentrations (Fig. 2). None of the elements were detected after the translocation experiment following the in vitro digestion (Fig. 2).
Polyethylene terephthalate microplastics

As expected only very few organic compounds were detected in polyethylene terephthalate (PET) (Fig. 6). These were limited to low concentrations of bis (2-ethylhexyl) phthalate $(1.7 \mathrm{mg} / \mathrm{kg})$, bis (2-propylpentyl) phthalate $(0.4$ $\mathrm{mg} / \mathrm{kg})$ and tributyl acetylcitrate $(0.6 \mathrm{mg} / \mathrm{kg})$. Tributyl acetylcitrate is a popular plasticizer that is used as a replacement for phthalates although no information was found about its presence in PET.

All three plasticizers were also found in the in vitro digestion, again at low concentrations $<1 \mathrm{mg} / \mathrm{kg}$ (Fig. 6). For tributyl acetylcitrate the concentration in the in vitro digestion is almost equal to that in the chemical leachate which may be explained by its moderate water solubility. Two of the plasticizers, bis (2-ethylhexyl) phthalate and tributyl acetylcitrate were also found after the translocation experiment following the in vitro digestion at concentrations of 0.1 and $0.3 \mathrm{mg} / \mathrm{kg}$, respectively (Fig. 6).

Only 8 elements were detected in PET, all in low concentrations with the exception of antimony $(\mathrm{Sb})$ which was found at a high concentration of $234 \mathrm{mg} / \mathrm{kg}$ (Fig. 2). Since antimony is used as a catalyst in the form of

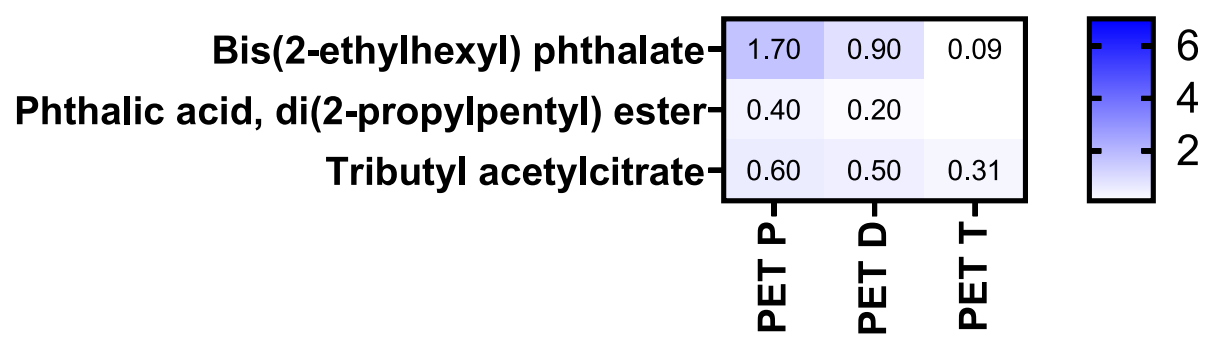

Fig. 6 Overview of chemicals (concentrations in $\mathrm{mg} / \mathrm{kg}$ microplastics) quantified in leachates of the polyethylene terephthalate polyethylene (PET) microplastics. P: chemicals in leachate from microplastics; D chemicals in intestinal chyme following in vitro digestion; T chemicals in basolateral compartment following exposure to in vitro epithelial Caco-2 cell layer 
compounds such as antimony trioxide $\left(\mathrm{Sb}_{2} \mathrm{O}_{3}\right)$ or antimony triacetate in the production of PET, its presence in this material is not surprising [60]. Of the other elements zirconium is found in a concentration of $1.3 \mathrm{mg} /$ $\mathrm{kg}$ while the others are all $<1 \mathrm{mg} / \mathrm{kg}$. Again, this is likely an artefact of the milling process.

Antimony is the only element which is found in the in vitro digestion be it in an already low concentration of $1.3 \mathrm{mg} / \mathrm{kg}$ (Fig. 2). None of the elements are found after the translocation experiment following the in vitro digestion (Fig. 2). This suggests that for PET microplastic particle exposure from drinking plastic bottled water, the potential for effects to manifest due to chemical leaching is low.

\section{Pre-production polypropylene microplastics}

In the pre-production sample of polypropylene microplastics (PP1) 11 organic compounds were detected in the chemical leachate (Fig. 7). These included low concentrations of the flame retardants tris (1-chloro-2-propyl) phosphate and tris (2-chloropropyl) phosphate and three plasticizers, bis (2-ethylhexyl) phthalate, dibutylphthalate and di (2-propylpentyl)phthalate. These industrial plasticizers may have been used to improve the mechanical properties of the polypropylene material. Other compounds that were detected are hexadecanoic acid and octadecanoic acid at higher concentrations of 2.1 and 7.6 $\mathrm{mg} / \mathrm{kg}$. Fatty acids are used in plastic moulding as external lubricants and release agents and may therefore be present in this material. Surprisingly, the material also contained three polycyclic aromatic hydrocarbons, naphthalene at a low concentration and higher concentrations of anthracene and phenanthrene. It is presently unclear why these compounds are found in the polypropylene microplastics.
Nine of the 11 detected compounds were also found in the in vitro digestion (Fig. 7). The highest concentrations are found for the two alkanoic acids, hexadecanoic acid at $2.6 \mathrm{mg} / \mathrm{kg}$ and octadecanoic acid at $5.4 \mathrm{mg} / \mathrm{kg}$, while the other compounds were found in concentrations of $1 \mathrm{mg} / \mathrm{kg}$ or lower. The two alkanoic acids are also found after translocation following the in vitro digestion (Fig. 7), indicating that a part of these alkanoic acids will be taken up in the body following ingestion of the microplastic material. Bis (2-ethylhexyl) phthalate was also found in a low concentration after translocation following the in vitro digestion.

In total 13 elements were detected in the polypropylene microplastics (Fig. 2). In the chemical digestion of the material a relatively high concentration of iron (116 $\mathrm{mg} / \mathrm{kg}$ ) was found while for barium a concentration of $16 \mathrm{mg} / \mathrm{kg}$ was found. In a detailed elemental analysis of different types of PP-based plastic also iron and barium was present a relatively high concentrations, while in that study also zinc was detected [59], which was absent in our PP microplastics. For the other elements concentrations were of 1.7 and $2.0 \mathrm{mg} / \mathrm{kg}$ were found for manganese and titanium respectively while concentrations < $1 \mathrm{mg} / \mathrm{kg}$ were found for the other elements.

Only iron was found in the in vitro digestion in a concentration of $4.7 \mathrm{mg} / \mathrm{kg}$ (Fig. 2). None of the elements were found after translocation following the in vitro digestion.

\section{Food container polypropylene microplastics}

The results for the organic compounds in the second polypropylene sample (PP 2; food container) are more or less identical to that of the first sample. 9 compounds

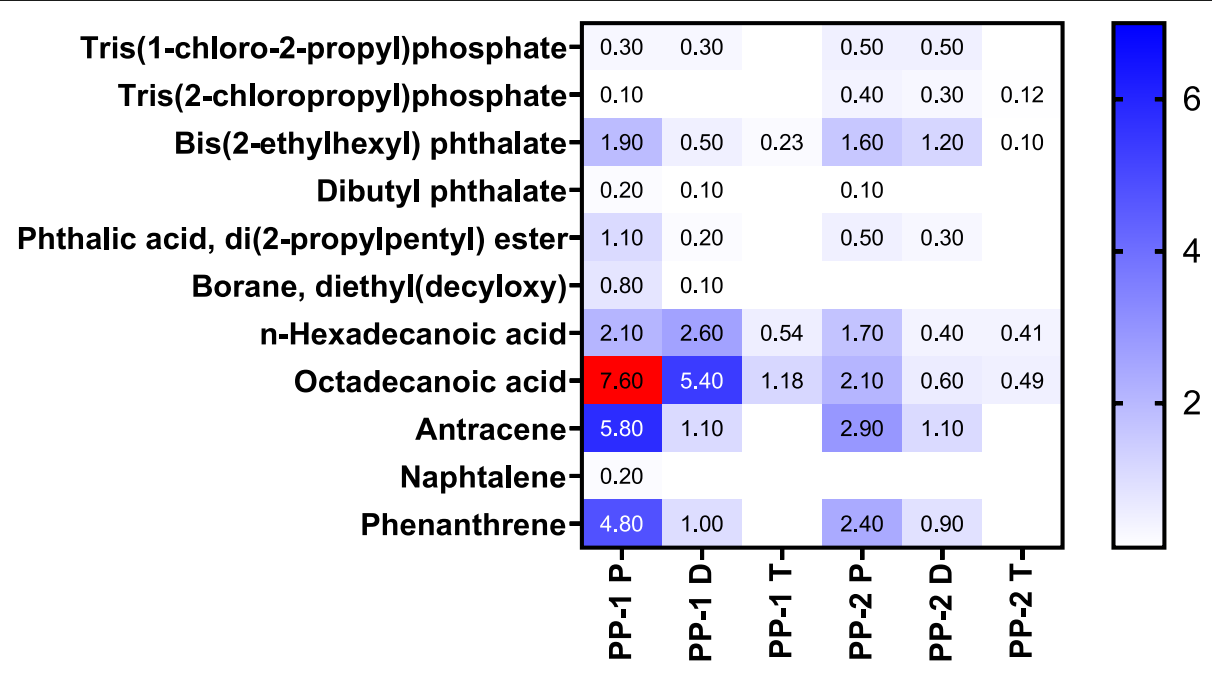

Fig. 7 Overview of chemicals (concentrations in $\mathrm{mg} / \mathrm{kg}$ microplastics) quantified in leachates of the polypropylene microplastics. PP-1: polypropylene type 1; PP-2: polypropylene type 2; P: chemicals in leachate from microplastics; D chemicals in intestinal chyme following in vitro digestion; T chemicals in basolateral compartment following exposure to in vitro epithelial Caco-2 cell layer. Red: value out of scale range 
are found including the 2 chlorinated phosphate flame retardants, the 3 phthalate plasticizers and the two alkanoic acids, hexadecanoic acid and octadecanoic acid (Fig. 7). Anthracene and phenanthrene were also found in this sample in concentrations of 2.9 and $2.4 \mathrm{mg} / \mathrm{kg}$, respectively. As mentioned before it is unclear where these PAHs come from and why they would be found in the plastic material. They were, however, excluded as contaminants in the analytical determination and identified based on retention time and full-scan mass spectrum.

All the identified compounds were also found in the in vitro digestion be it in lower concentrations (Fig. 7). The highest concentration of around $1 \mathrm{mg} / \mathrm{kg}$ were found for bis (2-ethylhexyl) phthalate and the two PAHs. Low concentrations of the hexadecanoic acid, octadecanoic acid, bis (2-ethylhexyl) phthalate and tris (2-chloropropyl) phosphate were found after translocation following the in vitro digestion indicating that some uptake of these compounds following ingestion of the microplastic material may take place (Fig. 7).

The elemental signature of this material is different from the first polypropylene sample (Fig. 2). Only 5 elements were detected with titanium in the highest concentration of $1.3 \mathrm{mg} / \mathrm{kg}$. The four other elements were found at concentrations $<1 \mathrm{mg} / \mathrm{kg}$. Higher concentrations of iron and barium, as found in the first polypropylene sample, were not found in this sample.

In the in vitro digestion and after the translocation following the in vitro digestion none of the elements were found. Element detection limits are $0.1 \mathrm{mg} / \mathrm{kg}$ in the in vitro digestion and $0.3 \mathrm{mg} / \mathrm{kg}$ in the translocation experiment.

\section{Polystyrene microplastics}

In the chemical leachate 31 organic compounds were identified (Fig. 8). These include the flame retardants trio-tolylphosphate and tris (1-chloro-2-propyl) phosphate in concentrations of 6.0 and $3.4 \mathrm{mg} / \mathrm{kg}$, the plasticizers bis (2-ethylhexyl) phthalate and dibutylphthalate in concentrations of 4.6 and $0.1 \mathrm{mg} / \mathrm{kg}$, and a large group of alkylbenzenes (not specified in the tables). The latter group consists of 24 alkylbenzenes and biphenylalkanes like 2-methylstyrene, isopropyltoluene, 1,3-diethylbenzene and 2,2',5,5' -tetramethyl-1,1'-biphenyl in concentrations ranging from 0.6 to $3.2 \mathrm{mg} / \mathrm{kg}$ and a total concentration of $30 \mathrm{mg} / \mathrm{kg}$. The presence of these alkylbenzenes and biphenylalkanes in the monomer styrene was already shown in 1977 [61]. They detected over 100 impurities and identified 60 of these compounds many of which were alkylbenzenes. Other compounds identified were benzaldehyde in a concentration of $3.9 \mathrm{mg} / \mathrm{kg}$ and the monomer styrene itself in a concentration of $3.6 \mathrm{mg} / \mathrm{kg}$. A low concentration of naphthalene, $0.2 \mathrm{mg} /$ $\mathrm{kg}$, was also found.

Many of the identified compounds were also found in the in vitro digestion (Fig. 8). This was especially true for the flame retardants tri-o-tolylphosphate and tris (1chloro-2-propyl) phosphate which were found in concentrations of 4.2 and $1.9 \mathrm{mg} / \mathrm{kg}$ in the in vitro digestion. As mentioned before it is probably the water solubility of these compounds that results in their relatively high concentrations in the in vitro digestion. Bis (2-ethylhexyl) phthalate was also found at a high concentration in the in vitro digestion and this is the only time that the concentration of a compound is higher in the in vitro digestion than in the chemical leachate. Of the

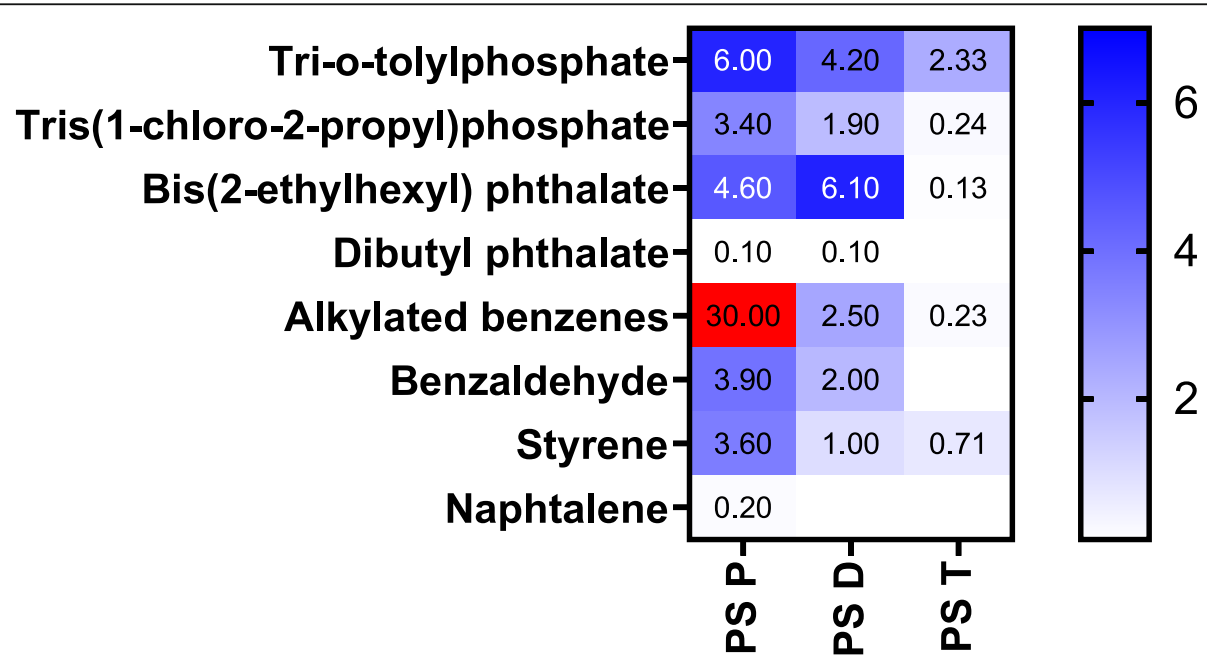

Fig. 8 Overview of chemicals (concentrations in mg/kg microplastics) quantified in leachates of the polystyrene (PS) microplastics. P:chemicals in leachate from microplastics; D chemicals in intestinal chyme following in vitro digestion; T chemicals in basolateral compartment following exposure to in vitro epithelial Caco-2 cell layer. Red: value out of scale range 
alkylbenzenes, $30 \mathrm{mg} / \mathrm{kg}$ in the chemical leachate, only a small fraction, $2.5 \mathrm{mg} / \mathrm{kg}$, is found in the in vitro digestion. Benzaldehyde and the monomer styrene were found in the in vitro digestion in concentrations of 2.0 and $1.0 \mathrm{mg} / \mathrm{kg}$, respectively. The monomer styrene was also found after the translocation following the in vitro digestion in a concentration of $0.7 \mathrm{mg} / \mathrm{kg}$ (Fig. 8). Tri-otolylphosphate was also present after the translocation and at a surprisingly high concentration of $2.3 \mathrm{mg} / \mathrm{kg}$. Low concentrations were found for tris (1-chloro-2-propyl) phosphate and bis (2-ethylhexyl)phthalate.

In total 7 elements were found in the chemical digestion of the polystyrene microplastics (Fig. 2). The highest concentrations were found for titanium $(11 \mathrm{mg} / \mathrm{kg})$ and copper $(5.3 \mathrm{mg} / \mathrm{kg})$. Lead was found in a concentration of 1.4 $\mathrm{mg} / \mathrm{kg}$ while the other elements, manganese, tin, tantalum and bismuth were found at concentrations $<1 \mathrm{mg} / \mathrm{kg}$.

In the in vitro digestion and after the translocation following the in vitro digestion none of the elements were found. Element detection limits are $0.1 \mathrm{mg} / \mathrm{kg}$ in the in vitro digestion and $0.3 \mathrm{mg} / \mathrm{kg}$ in.
Polyvinylchloride microplastics

In the chemical leachate of the polyvinylchloride (PVC) microplastics 17 compounds were identified. These include the flame retardants tri-isobutylphosphate at a concentration of $1.0 \mathrm{mg} / \mathrm{kg}$ and traces of the chlorinated phosphates (Fig. 9). Bis (2-ethylhexyl) phthalate was found at a concentration of $4.2 \mathrm{mg} / \mathrm{kg}$ and di (2-propylpentyl) phthalate at a concentration of $1.2 \mathrm{mg} / \mathrm{kg}$. Two more phthalates were found at low concentrations. Dicarboxylic acid esters are also used as plasticizers and were also found in the chemical leachate, hexanedioic acid, bis (2ethylhexyl) ester at a concentration of $6.7 \mathrm{mg} / \mathrm{kg}$, pentanedioic acid, dimethyl ester at a concentration of $3.0 \mathrm{mg} / \mathrm{kg}$, butanedioic acid, dimethyl ester at a concentration of 2.6 $\mathrm{mg} / \mathrm{kg}$ and hexanedioic acid, dimethyl ester at a concentration of $1.0 \mathrm{mg} / \mathrm{kg}$. A chlorinated alkylbenzene, 1-(chloromethyl)-2-methylbenzene was found at a concentration of $2.0 \mathrm{mg} / \mathrm{kg}$ in the chemical leachate. Naphthalene was found at a concentration of $0.5 \mathrm{mg} / \mathrm{kg}$.

A number of the compounds identified in the chemical leachate were also found in the in vitro

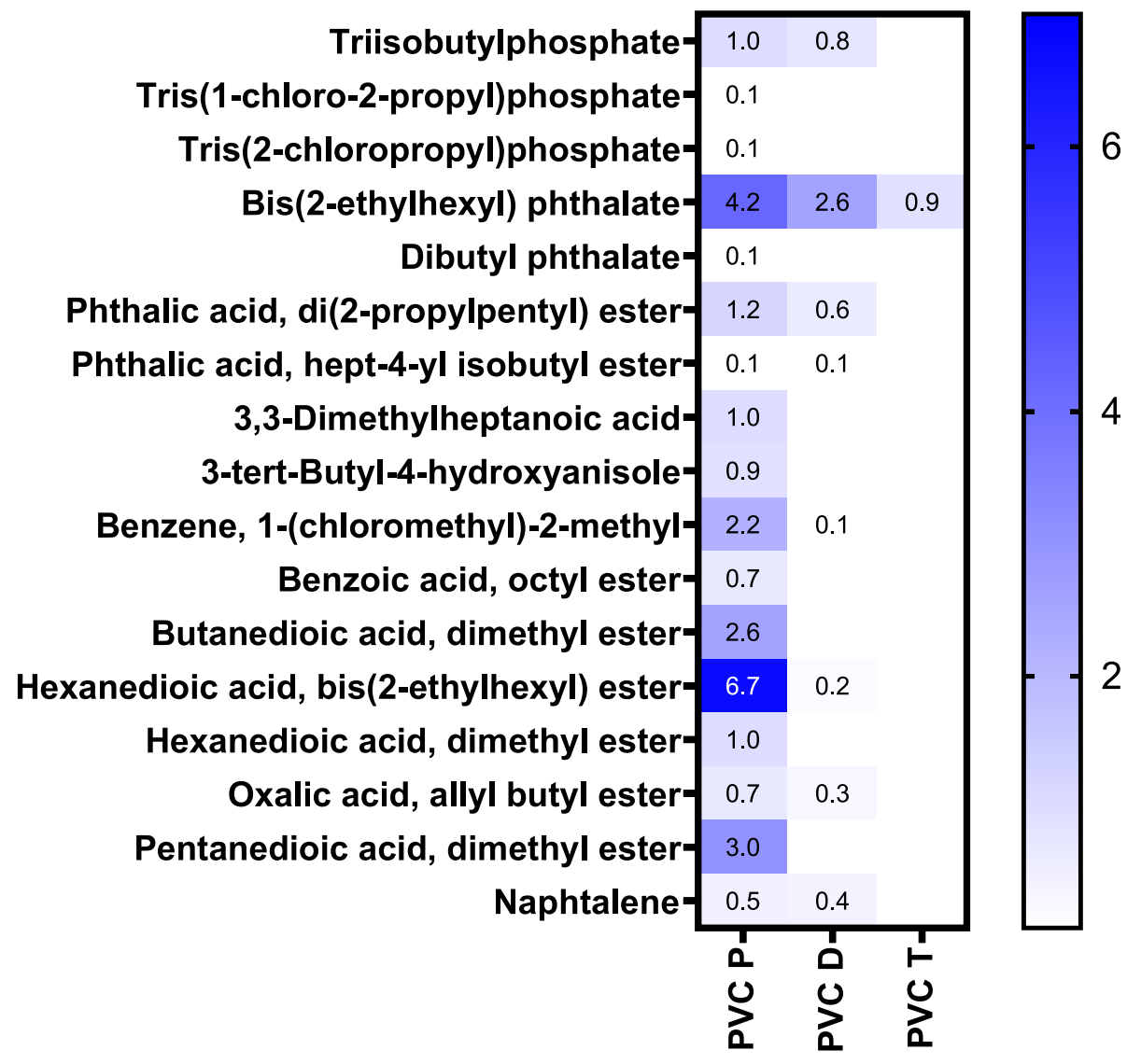

Fig. 9 Overview of chemicals (concentrations in mg/kg microplastics) quantified in leachates of the polyvinylchloride (PVC) microplastics. P: chemicals in leachate from microplastics; D chemicals in intestinal chyme following in vitro digestion; T chemicals in basolateral compartment following exposure to in vitro epithelial Caco-2 cell layer 
digestion (Fig. 9). These include tri-isobutylphosphate, bis (2-ethylhexyl) phthalate and di (2-propylpentyl)phthalate. Of the dicarboxylic acid esters only hexanedioic acid, bis (2-ethylhexyl) ester was found in the in vitro digestion at a low concentration. Naphthalene was also found in the in vitro digestion in a concentration of $0.5 \mathrm{mg} / \mathrm{kg}$. Bis (2-ethylhexyl) phthalate was the only compound that was found after the translocation following the in vitro digestion at a concentration of $0.9 \mathrm{mg} / \mathrm{kg}$.

In total 15 elements were detected in the chemical digestion of the PVC microplastics (Fig. 2). The highest concentration was $260 \mathrm{mg} / \mathrm{kg}$ and was found for zinc, which confirms earlier findings were zinc was present in PVC most abundantly, followed by high concentrations of iron [59], which was not detected in our PVC sample. Zinc stearate is used as a heat stabilizer in PVC so its appearance is not unexpected. The concentrations of all other elements were $<2 \mathrm{mg} / \mathrm{kg}$. In the in vitro digestion and after the translocation following the in vitro digestion none of the elements were found. Element detection limits are $0.1 \mathrm{mg} / \mathrm{kg}$ in the in vitro digestion and $0.3 \mathrm{mg} /$ $\mathrm{kg}$ in the translocation experiment.

\section{Initial hazard assessment of chemicals in leachates from microplastics}

Microplastics released into the environment during the product life cycle and degraded from plastic waste and items during use are complex chemical mixtures, that can have different sizes, various shapes, can have different polymeric composition and can contain mixtures of chemicals. Human exposure to microplastics might therefore represent both particle and chemical related hazards [52]. In this work we determined the chemical composition of chemical leachates from 9 types of microplastics under stringent chemical digestion conditions and physiologically realistic conditions simulated in vitro. Microplastics samples collected from Dutch beaches contained the largest number of different chemicals (i.e. 32 and 25 different chemicals for the $<1 \mathrm{~mm}$ and $<3 \mathrm{~mm}$ microplastics respectively), while PE microplastics contained 5 different chemicals (number of chemical in different microplastics: Env-1 $>$ Env-3 $>$ PVC $>$ PA $>$ PP $>$ PE $>$ PET). Only a few studies have assessed the chemical composition of different types of plastic [24, 62]. The environmental microplastics have been previously characterized [9], and the chemical analysis of plastic consumer products reported that PVC contained more chemicals than PP and PET plastics [24]. In our study a comparable trend was observed, while we analysed pre-production PVC.

It is still not possible to perform a comprehensive risk assessment of human exposure to microplastics [52]. Of the chemicals found to be associated with microplastics that translocated basolaterally using an in vitro model of the intestinal epithelium, only for some detailed exposure and toxicity data is available. Only $50 \%$ of the identified chemicals were listed in the ToxCast database, and of these only a limited number have been screened for endocrine disrupting potency using in vitro screening assays (i.e. activation of the estrogen receptor, activation of the androgen receptor, aryl hydrocarbon receptor of induced oxidative stress; see Table 3). This is also reflected by an analysis of the adverse outcome pathways that might be activated by the chemicals associated with the microplastics. From the ToxCast dataset we extracted 18 AOPs that were associated with the chemicals (Fig. 10), that included AOPs associated with endocrine disruption (i.e. AOP 150: Ah-receptor activation; AOP 200: Estrogen receptor activation, and several AOP that involve the activation of other nuclear receptors AOPs (i.e. AOP $58,107,163) .50 \%$ of the chemicals that were shown to pass the epithelial intestinal cell layer in vitro are associated with activation of the estrogen receptor (AOP 200). Recent toxicological screening studies indicated that microplastics (as particle or in combination with associated chemicals) induce oxidative stress and endocrine activity pathways in reporter gene assays [24, 62]. Recently the hazards of plastic packaging associated chemicals have been reviewed in detail [63]. These authors indicate that 906 chemicals can be associated with plastic packaging materials, of which 34 are recognized as endocrine disrupting chemicals [63]. While local exposure of the gastrointestinal epithelium might be high, systemic availability of metals associated with microplastics following oral exposure seems to negligible, as only iron (Fe) from ENV microplastics was detected in the basolateral compartment of the in vitro human epithelial cell layer model.

Clearly, from this work and that of others it can be concluded that microplastics should be regarded as a potential source of human exposure to chemicals that have an endocrine disrupting potency and might trigger AOPs related to nuclear receptor activation. For a risk assessment of the microplastics associated chemicals the contribution of chemical exposure via microplastics is needed, that is differentiated from the background exposure to these chemicals. Results from a study in fish larvae fed with PE and PS microplastics to which PCBs were sorbed under experimental conditions, indicate a minimal contribution of the PCB exposure via microplastics [64]. It is not yet known if this can be extrapolated to other microplastics associated chemicals. Yet, combination effects of the microplastics potentially affecting the barrier properties of the intestinal epithelial, resulting in an increase uptake need to be studied in more detail [65]. An important knowledge gap to improve the exposure assessment of chemical associated 


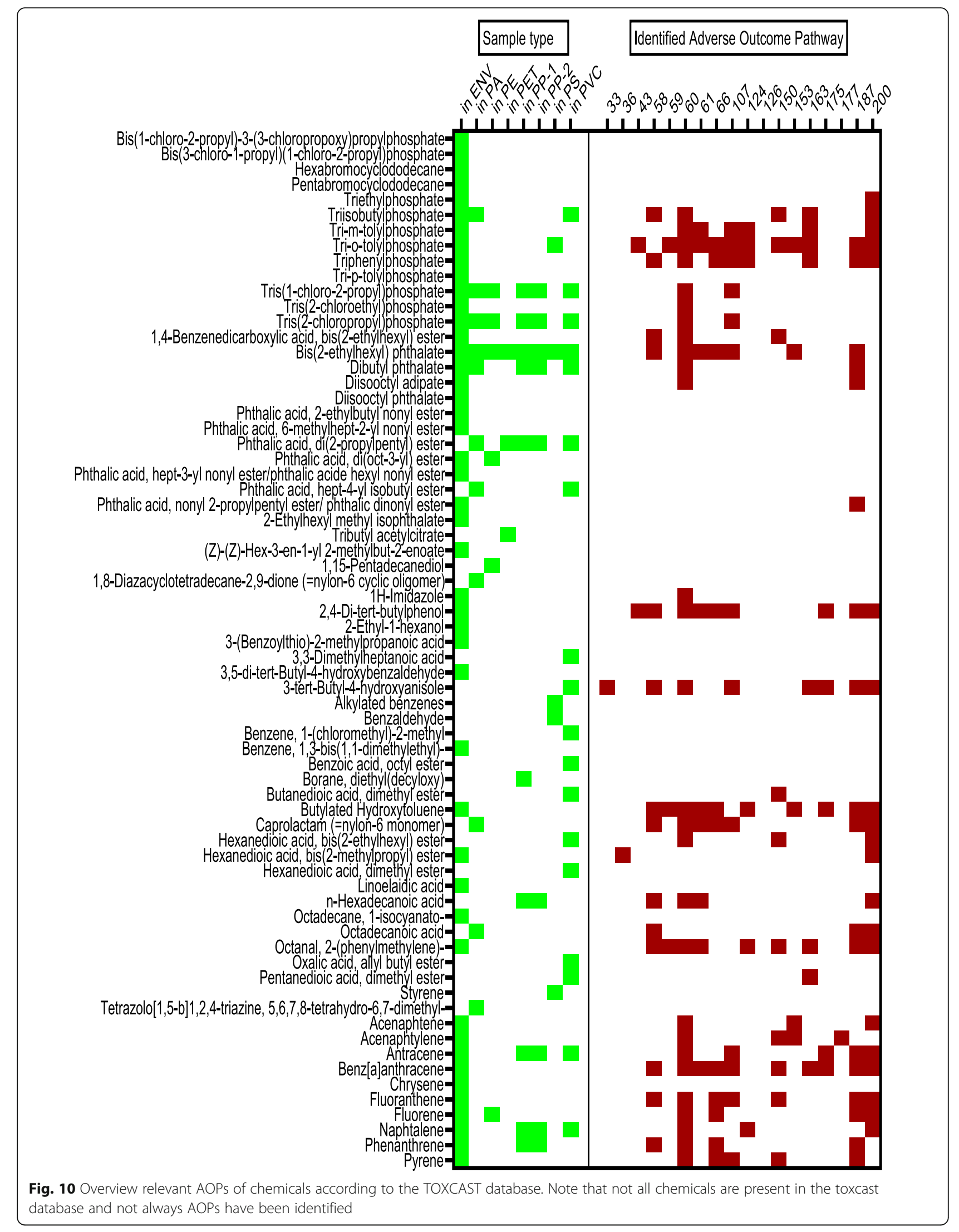


microplastics is the extent to which humans are exposed to microplastics. Recently it was predicted that adults human consume 553 microplastics /person/day resulting in an accumulation of $5.01 \times 10^{4}$ particles for adults until the age of 70 (re-scaled microplastics $1-10 \mu \mathrm{m}$ ) [22]. In this study microplastics were re-scaled limiting the possibility to link the chemical data per polymer type microplastics to this. Others have estimated an annual human exposure to microplastics through food of $1.42 \times$ $10^{5}-1.54 \times 10^{5}$ particles/capita for general population which represent $0.13-2.04 \mathrm{~g}$ microplastic/capita/day (average $1.08 \mathrm{microplastic/capita/day)} \mathrm{[41],} \mathrm{this} \mathrm{could}$ result in an exposure in the low $\mu \mathrm{g} / \mathrm{capita} /$ day range to individual chemicals detected in chyme.

\section{Conclusion}

Using sensitive GC-MS methods we quantified 68 chemicals associated with a diversity of microplastics ranging from pre-productions materials to microplastics derived from plastic beach litter. Some of these chemicals were released to the lumen of the human digestive tract under physiological conditions, simulated in vitro. Only 22 chemicals reached the basolateral compartment of an in vitro intestinal epithelial model, suggesting that only these 22 chemicals could reach systemic circulation. Of the quantified chemicals, only $50 \%$ has been evaluated in the ToxCast program. From the ToxCast dataset we extracted 18 AOPs that were associated with the chemicals, that included AOPs associated with endocrine disruption. A rough estimation of the potential human oral exposure to chemical leachates present in chyme can be made, and for individual compounds to oral exposure to individual chemicals in leachates from microplastics is in the low $\mu \mathrm{g} / \mathrm{capita} /$ day range. However, for a risk assessment of chemicals associated with microplastics more detailed data on oral microplastics exposure is needed, as well as more detailed toxicological studies on the hazards of both the individual chemicals, complex chemical mixtures of the quantified chemicals as well as mixtures of microplastics.

\section{Acknowledgements}

We thank Suze Kuhn for kindly making the environmental microplastics available for our study. Support in laboratory work was kindly provided by Anna Undas from Wageningen Food Safety Research, Wageningen.

\section{Peer review}

IIn keeping with research integrity principles, all SCCWRP workshop articles co-authored by Dr. Steve Weisberg, Dr. Albert Koelmans, and other Microplastics and Nanoplastics editors were handled by independent editors of the journal.

\section{Authors' contributions}

$\mathrm{RP}, \mathrm{HB}$ and SW developed the idea for this study, NdJ and LdH performed the experiments, RP and HB analysed the data and together with SW drafted the manuscript. The authors read and approved the final manuscript.

\section{Funding}

Funding for this study was received form the ZonMW breakthrough project on microplastics grant number 458001001 (to RP, LdH, SW and HB). Open Access funding was enabled and organized by the southern California coastal Water Research Project.

\section{Availability of data and materials}

The datasets used and/or analysed during the current study are available from the corresponding author on reasonable request.

\section{Declarations}

\section{Competing interests}

The authors declare that they have no competing interests.

\section{Author details}

${ }^{1}$ Wageningen Food Safety Research, Wageningen University \& Research, Wageningen, The Netherlands. ${ }^{2}$ Division of Toxicology, Wageningen University \& Research, Wageningen, the Netherlands. ${ }^{3}$ Environmental Research Group, MRC Centre for Environment \& Health, School of Public Health, Imperial College London, Sir Michael Uren Hub, White City Campus, London W12 OBZ, UK.

Received: 26 October 2021 Accepted: 9 December 2021

Published online: 21 January 2022

\section{References}

1. Geyer R, Jambeck JR, Law KL. Production, use, and fate of all plastics ever made. Sci Adv. 2017;3(7):e1700782. https://doi.org/10.1126/sciadv.1700782.

2. Rubio L, Marcos R, Hernandez A. Potential adverse health effects of ingested micro- and nanoplastics on humans. Lessons learned from in vivo and in vitro mammalian models. J Toxicol Environ Health B Crit Rev. 2020;23(2): 51-68. https://doi.org/10.1080/10937404.2019.1700598.

3. Cole M, Lindeque P, Halsband C, Galloway TS. Microplastics as contaminants in the marine environment: a review. Mar Pollut Bull. 2011;62(12):2588-97. https://doi.org/10.1016/j.marpolbul.2011.09.025.

4. Jambeck JR, Geyer R, Wilcox C, Siegler TR, Perryman M, Andrady A, et al. Marine pollution. Plastic waste inputs from land into the ocean. Science. 2015;347(6223):768-71. https://doi.org/10.1126/science.1260352.

5. ISO. Reference International Organization for Standardization. Plastics Environmental aspects - State of knowledge and methodologies, ISO/TR 21960:2020. 2020.

6. Alexander J, Barregard L, Bignami M, Ceccatelli S, Cottrill B, Dinovi M, et al. Presence of microplastics and nanoplastics in food, with particular focus on seafood. Efsa J. 2016;14(6):e04501.

7. Bouwmeester $\mathrm{H}$, Hollman PC, Peters RJ. Potential health impact of environmentally released Micro- and Nanoplastics in the human food production chain: experiences from Nanotoxicology. Environ Sci Technol. 2015;49(15):8932-47. https://doi.org/10.1021/acs.est.5b01090.

8. Cozar A, Echevarria F, Gonzalez-Gordillo JI, Irigoien X, Ubeda B, HernandezLeon S, et al. Plastic debris in the open ocean. Proc Natl Acad Sci U S A. 2014;111(28):10239-44. https://doi.org/10.1073/pnas.1314705111.

9. Kuhn S, van Oyen A, Booth AM, Meijboom A, van Franeker JA. Marine microplastic: preparation of relevant test materials for laboratory assessment of ecosystem impacts. Chemosphere. 2018;213:103-13. https://doi.org/10.1 016/j.chemosphere.2018.09.032.

10. Kuhn S, van Oyen A, Bravo Rebolledo EL, Ask AV, van Franeker JA. Polymer types ingested by northern fulmars (Fulmarus glacialis) and southern hemisphere relatives. Environ Sci Pollut Res Int. 2021;28(2):1643-55. https:// doi.org/10.1007/s11356-020-10540-6.

11. Wright SL, Kelly FJ. Plastic and human health: a Micro issue? Environ Sci Technol. 2017;51(12):6634-47. https://doi.org/10.1021/acs.est.7b00423.

12. WHO. Microplastics in drinking-water. Geneva: World Health Organization; 2019.

13. Schwabl P, Köppel S, Königshofer P, Bucsics T, Trauner M, Reiberger T, et al. Detection of Various Microplastics in Human Stool: A Prospective Case Series Contamination of table salts from Turkey with microplastics Plastics contamination of store-bought rice. (1539-3704 (Electronic)).

14. Barboza LGA, Dick Vethaak A, Lavorante B, Lundebye AK, Guilhermino L. Marine microplastic debris: an emerging issue for food security, food safety and human health. Mar Pollut Bull. 2018;133:336-48. https://doi.org/10.1016/ j.marpolbul.2018.05.047. 
15. Dessi C, Okoffo ED, O'Brien JW, Gallen M, Samanipour S, Kaserzon S, et al. Plastics contamination of store-bought rice. J Hazard Mater. 2021;416: 125778.

16. Gundogdu S. Contamination of table salts from Turkey with microplastics. Food Addit Contam Part A: Chem Anal Control Expo Risk Assess. 2018;35(5): 1006-14. https://doi.org/10.1080/19440049.2018.1447694.

17. RASFF. Rapid Alert System for Food and Feed. Retrieved from https://webga te.ec.europa.eu/rasff-window/portal/?event=searchResultList. 2020.

18. Kosuth M, Mason SA, Wattenberg EV. Anthropogenic contamination of tap water, beer, and sea salt. PLoS One. 2018;13(4):e0194970. https://doi.org/1 0.1371/journal.pone.0194970.

19. Schymanski D, Goldbeck C, Humpf HU, Furst P. Analysis of microplastics in water by micro-Raman spectroscopy: release of plastic particles from different packaging into mineral water. Water Res. 2018;129:154-62. https:// doi.org/10.1016/j.watres.2017.11.011.

20. Kutralam-Muniasamy G, Pérez-Guevara F, Elizalde-Martínez I, Shruti VC. How well-protected are protected areas from anthropogenic microplastic contamination? Review of analytical methods, current trends, and prospects. Trends Environ Anal Chem. 2021;32:e00147. https://doi.org/10.1016/j.teac.2 021.e00147.

21. Cox KD, Covernton GA, Davies HL, Dower JF, Juanes F, Dudas SE. Human consumption of microplastics. Environ Sci Technol. 2019;53(12):7068-74. https://doi.org/10.1021/acs.est.9b01517.

22. Mohamed Nor NH, Kooi M, Diepens NJ, Koelmans AA. Lifetime accumulation of microplastic in children and adults. Environ Sci Technol. 2021;55(8):5084-96. https://doi.org/10.1021/acs.est.0c07384.

23. Catarino Al, Macchia V, Sanderson WG, Thompson RC, Henry TB. Low levels of microplastics (MP) in wild mussels indicate that MP ingestion by humans is minimal compared to exposure via household fibres fallout during a meal. Environ Pollut. 2018;237:675-84. https://doi.org/10.1016/j.envpol.2018. 02.069 .

24. Zimmermann L, Dierkes G, Ternes TA, Volker C, Wagner M. Benchmarking the in vitro toxicity and chemical composition of plastic consumer products. Environ Sci Technol. 2019;53(19):11467-77. https://doi.org/10.1 021/acs.est.9b02293.

25. Hahladakis JN, Velis CA, Weber R, lacovidou E, Purnell P. An overview of chemical additives present in plastics: migration, release, fate and environmental impact during their use, disposal and recycling. J Hazard Mater. 2018;344:179-99. https://doi.org/10.1016/j.jhazmat.2017.10.014.

26. Meeker JD, Sathyanarayana S, Swan SH. Phthalates and other additives in plastics: human exposure and associated health outcomes. Philos Trans R Soc Lond Ser B Biol Sci. 2009;364(1526):2097-113. https://doi.org/10.1098/ rstb.2008.0268.

27. Teuten EL, Saquing JM, Knappe DR, Barlaz MA, Jonsson S, Bjorn A, et al. Transport and release of chemicals from plastics to the environment and to wildlife. Philos Trans R Soc Lond Ser B Biol Sci. 2009;364(1526):2027-45. https://doi.org/10.1098/rstb.2008.0284.

28. Muncke J. Exposure to endocrine disrupting compounds via the food chain: is packaging a relevant source? Sci Total Environ. 2009;407(16):4549-59. https://doi.org/10.1016/j.scitotenv.2009.05.006.

29. Koelmans AA, Bakir A, Burton GA, Janssen CR. Microplastic as a vector for Chemicals in the Aquatic Environment: critical review and model-supported reinterpretation of empirical studies. Environ Sci Technol. 2016;50(7):331526. https://doi.org/10.1021/acs.est.5b06069.

30. Wu P, Huang J, Zheng Y, Yang Y, Zhang Y, He F, et al. Environmental occurrences, fate, and impacts of microplastics. Ecotoxicol Environ Saf. 2019; 184:109612. https://doi.org/10.1016/j.ecoenv.2019.109612.

31. Rodrigues JP, Duarte AC, Santos-Echeandia J, Rocha-Santos T. Significance of interactions between microplastics and POPs in the marine environment a critical overview. Trac-Trend Anal Chem. 2019;111:252-60. https://doi.org/1 0.1016/j.trac.2018.11.038.

32. Mato $Y$, Isobe $T$, Takada H, Kanehiro H, Ohtake C, Kaminuma T. Plastic resin pellets as a transport medium for toxic chemicals in the marine environment. Environ Sci Technol. 2001;35(2):318-24. https://doi.org/10.1 021/es0010498.

33. Rochman CM, Hoh E, Kurobe T, Teh SJ. Ingested plastic transfers hazardous chemicals to fish and induces hepatic stress. Sci Rep. 2013;3(1):3263. https:// doi.org/10.1038/srep03263.

34. Mendoza LMR, Jones PR. Characterisation of microplastics and toxic chemicals extracted from microplastic samples from the North Pacific gyre. Environ Chem. 2015;12(5):611-7. https://doi.org/10.1071/EN14236.
35. Brennecke D, Duarte B, Paiva F, Cacador I, Canning-Clode J. Microplastics as vector for heavy metal contamination from the marine environment. Estuar Coast Shelf Sci. 2016;178:189-95. https://doi.org/10.1016/j.ecss.2015.12.003.

36. Wang Z, Chen M, Zhang L, Wang K, Yu X, Zheng Z, et al. Sorption behaviors of phenanthrene on the microplastics identified in a mariculture farm in Xiangshan Bay, southeastern China. Sci Total Environ. 2018;628-629:1617-26.

37. Wang W, Wang J. Different partition of polycyclic aromatic hydrocarbon on environmental particulates in freshwater: microplastics in comparison to natural sediment. Ecotoxicol Environ Saf. 2018;147:648-55. https://doi.org/1 0.1016/j.ecoenv.2017.09.029.

38. Li J, Zhang K, Zhang H. Adsorption of antibiotics on microplastics. Environ Pollut. 2018;237:460-7. https://doi.org/10.1016/j.envpol.2018.02.050.

39. Bakir A, Rowland SJ, Thompson RC. Enhanced desorption of persistent organic pollutants from microplastics under simulated physiological conditions. Environ Pollut. 2014;185:16-23. https://doi.org/10.1016/j.envpol.2 013.10.007.

40. Bagel S, Dessaigne B, Bourdeaux D, Boyer A, Bouteloup C, Bazin J-E, et al. Influence of lipid type on Bis (2-ethylhexyl) phthalate (DEHP) leaching from infusion line sets in parenteral nutrition. J Parenter Enter Nutr. 2011;35(6): 770-5. https://doi.org/10.1177/0148607111414021.

41. Bai C-L, Liu L-Y, Hu Y-B, Zeng EY, Guo Y. Microplastics: a review of analytical methods, occurrence and characteristics in food, and potential toxicities to biota. Sci Total Environ. 2022;806(Pt 1):150263. https://doi.org/10.1016/j. scitotenv.2021.150263.

42. Li D, Shi Y, Yang L, Xiao L, Kehoe DK, Gun'ko YK, et al. Microplastic release from the degradation of polypropylene feeding bottles during infant formula preparation. Nat Food. 2020;1(11):746-54. https://doi.org/10.1038/ s43016-020-00171-y.

43. Sobhani Z, Lei Y, Tang Y, Wu L, Zhang X, Naidu R, et al. Microplastics generated when opening plastic packaging. Sci Rep. 2020;10(1):4841. https://doi.org/10.1038/s41598-020-61146-4.

44. Linsinger $T$, Liebich A, Przyk $E$, Lamberty $A$. The certification of the mass fraction of as, $\mathrm{Br}, \mathrm{Cd}, \mathrm{Cl}, \mathrm{Cr}, \mathrm{hg}, \mathrm{Pb}, \mathrm{S}$ and $\mathrm{Sb}$ and the assignment of indicative values for $\mathrm{Sn}$ and $\mathrm{Zn}$ in two polyethylene reference materials, ERM $^{\oplus}$-EC680k and ERM ${ }^{\oplus}$-EC681k EUR 22784 EN - DG Joint Research Centre, Institute for Reference Materials and Measurements 2007.

45. Versantvoort CH, Oomen AG, Van de Kamp E, Rompelberg CJ, Sips AJ. Applicability of an in vitro digestion model in assessing the bioaccessibility of mycotoxins from food. Food Chem Toxicol. 2005;43(1):31-40. https://doi. org/10.1016/j.fct.2004.08.007.

46. Abdelkhaliq A, van der Zande M, Undas AK, Peters RJB, Bouwmeester H. Impact of in vitro digestion on gastrointestinal fate and uptake of silver nanoparticles with different surface modifications. Nanotoxicology. 2020; 14(1):111-26. https://doi.org/10.1080/17435390.2019.1675794.

47. Hubatsch I, Ragnarsson EG, Artursson P. Determination of drug permeability and prediction of drug absorption in Caco-2 monolayers. Nat Protoc. 2007; 2(9):2111-9. https://doi.org/10.1038/nprot.2007.303.

48. Walczak AP, Kramer E, Hendriksen PJ, Tromp P, Helsper JP, van der Zande M, et al. Translocation of differently sized and charged polystyrene nanoparticles in in vitro intestinal cell models of increasing complexity. Nanotoxicology. 2015;9(4):453-61. https://doi.org/10.3109/17435390.2014.944599.

49. Walczak AP, Kramer E, Hendriksen PJ, Helsdingen R, van der Zande M, Rietjens IM, et al. In vitro gastrointestinal digestion increases the translocation of polystyrene nanoparticles in an in vitro intestinal co-culture model. Nanotoxicology. 2015;9(7):886-94. https://doi.org/10.3109/174353 90.2014.988664.

50. ToxCast. EPA ToxCast data [Available from: https://www.epa.gov/chemicalresearch/exploring-toxcast-data-downloadable-data. Accessed Sept 2021.

51. IARC. monographs on the identification of carcinogenic hazards to humans [Available from: https://monographs.iarc.who.int/agents-classified-by-the-iarc/. Accessed Sept 2021.

52. Vethaak AD, Legler J. Microplastics and human health. Science. 2021; 371(6530):672-4. https://doi.org/10.1126/science.abe5041.

53. Proenca S, Escher Bl, Fischer FC, Fisher C, Gregoire S, Hewitt NJ, et al. Effective exposure of chemicals in in vitro cell systems: a review of chemical distribution models. Toxicol Vitro. 2021;73:105133. https://doi.org/10.1016/j. tiv.2021.105133.

54. Stenvall E, Tostar S, Boldizar A, Foreman MR, Moller K. An analysis of the composition and metal contamination of plastics from waste electrical and electronic equipment (WEEE). Waste Manag. 2013;33(4):915-22. https://doi. org/10.1016/j.wasman.2012.12.022. 
55. Aksın Artok Ö, Schiller M, Everard M. Metal soaps under the view point of sustainability—one vision. J Vinyl Addit Technol. 2017;23(2):125-34. https:// doi.org/10.1002/vnl.21487.

56. Borukaev TA, Kitieva LI, Sultigova ZK, Martazova RM. Complex stabilizer based on calcium and zinc stearates for pvc compounds. Key Eng Mat. 2020:218-23.

57. Kang SG, Zhu JX. Total lead content and its bioaccessibility in base materials of low-cost plastic toys bought on the Beijing market. J Mater Cycles Waste. 2015;17(1):63-71. https://doi.org/10.1007/s10163-013-0223-9.

58. Zanzottera $\mathrm{C}$, Hamers $\mathrm{H}$, Howie B. Extending the boundaries: Bismuth-based pigments for the plastics industry. In: Annual Technical Conference - ANTEC, Conference Proceedings; 2018.

59. Klöckner P, Reemtsma T, Wagner $\mathrm{S}$. The diverse metal composition of plastic items and its implications. Sci Total Environ. 2021;764:142870. https:// doi.org/10.1016/j.scitotenv.2020.142870.

60. Westerhoff $P$, Prapaipong P, Shock E, Hillaireau A. Antimony leaching from polyethylene terephthalate (PET) plastic used for bottled drinking water. Water Res. 2008;42(3):551-6. https://doi.org/10.1016/j.watres.2007.07.048.

61. Zlatkis A, Anderson JW, Holzer G. Concentration and analysis of trace impurities in styrene monomer. J Chromatogr. 1977;142(Nov):127-9. https:// doi.org/10.1016/S0021-9673(01)92032-1.

62. Rummel CD, Escher Bl, Sandblom O, Plassmann MM, Arp HPH, MacLeod M, et al. Effects of Leachates from UV-weathered microplastic in cell-based bioassays. Environ Sci Technol. 2019;53(15):9214-23. https://doi.org/10.1 021/acs.est.9b02400.

63. Groh K, Backhaus T, Carney-Almroth B, Geueke B, Inostroza PA, Lennquist A et al. Overview of known plastic packaging-associated chemicals and their hazards. Sci Total Environ. 2019;651(Pt 2):3253-68. https://doi.org/10.1016/j. scitotenv.2018.10.015.

64. Norland S, Vorkamp K, Bogevik AS, Koelmans AA, Diepens NJ, Burgerhout E, et al. Assessing microplastic as a vector for chemical entry into fish larvae using a novel tube-feeding approach. Chemosphere. 2021;265:129144. https://doi.org/10.1016/j.chemosphere.2020.129144.

65. Liang $B$, Zhong $Y$, Huang $Y$, Lin $X$, Liu J, Lin L, et al. Underestimated health risks: polystyrene micro- and nanoplastics jointly induce intestinal barrier dysfunction by ROS-mediated epithelial cell apoptosis. Part Fibre Toxicol. 2021;18(1):20. https://doi.org/10.1186/s12989-021-00414-1.

\section{Publisher's Note}

Springer Nature remains neutral with regard to jurisdictional claims in published maps and institutional affiliations.

\section{Submit your manuscript to a SpringerOpen ${ }^{\circ}$ journal and benefit from:}

- Convenient online submission

- Rigorous peer review

- Open access: articles freely available online

- High visibility within the field

- Retaining the copyright to your article

Submit your next manuscript at $\boldsymbol{\nabla}$ springeropen.com 